\title{
The Penicillium chrysogenum Q176 Antimicrobial Protein PAFC Effectively Inhibits the Growth of the Opportunistic Human Pathogen Candida albicans
}

\author{
Jeanett Holzknecht ${ }^{1}$, Alexander Kühbacher ${ }^{1}$, Csaba Papp ${ }^{2}$, , Attila Farkas ${ }^{3}$, Györgyi Váradi ${ }^{4}$,

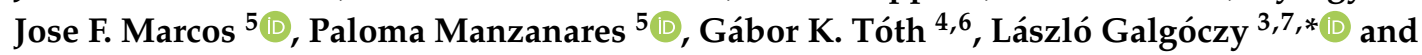 \\ Florentine Marx 1,*(D) \\ 1 Biocenter, Institute of Molecular Biology, Medical University of Innsbruck, Innrain 80-82, A-6020 Innsbruck, \\ Austria; jeanett.holzknecht@i-med.ac.at (J.H.); alexander.kuehbacher@i-med.ac.at (A.K.) \\ 2 Department of Microbiology, Faculty of Science and Informatics, University of Szeged, Közép fasor 52, \\ H-6726 Szeged, Hungary; papp.cs66@gmail.com \\ 3 Institute of Plant Biology, Biological Research Centre, Temesvári krt. 62, H-6726 Szeged, Hungary; \\ farkas.attila@brc.hu \\ 4 Department of Medical Chemistry, Faculty of Medicine, University of Szeged, Dóm tér 8, H-6720 Szeged, \\ Hungary; varadi.gyorgyi@med.u-szeged.hu (G.V.); toth.gabor@med.u-szeged.hu (G.K.T.) \\ 5 Department of Food Biotechnology, Instituto de Agroquímica y Tecnología de Alimentos (IATA-CSIC), \\ Consejo Superior de Investigaciones Científicas (CSIC), Paterna, E-46980 Valencia, Spain; \\ jmarcos@iata.csic.es (J.F.M.); pmanz@iata.csic.es (P.M.) \\ 6 MTA-SZTE Biomimetic Systems Research Group, University of Szeged, Dóm tér 8, H-6726 Szeged, Hungary \\ 7 Department of Biotechnology, Faculty of Science and Informatics, University of Szeged, Közép fasor 52, \\ H-6726 Szeged, Hungary \\ * Correspondence: galgoczi.laszlo@brc.hu (L.G.); florentine.marx@i-med.ac.at (F.M.); \\ Tel.: +36-62-599-600 (ext. 415) (L.G.); +43-512-9003 (ext. 70207) (F.M.)
}

Received: 10 July 2020; Accepted: 11 August 2020; Published: 19 August 2020

\begin{abstract}
Small, cysteine-rich and cationic antimicrobial proteins (AMPs) from filamentous ascomycetes promise treatment alternatives to licensed antifungal drugs. In this study, we characterized the Penicillium chrysogenum Q176 antifungal protein C (PAFC), which is phylogenetically distinct to the other two Penicillium antifungal proteins, PAF and PAFB, that are expressed by this biotechnologically important ascomycete. PAFC is secreted into the culture broth and is co-expressed with PAF and PAFB in the exudates of surface cultures. This observation is in line with the suggested role of AMPs in the adaptive response of the host to endogenous and/or environmental stimuli. The in silico structural model predicted five $\beta$-strands stabilized by four intramolecular disulfide bonds in PAFC. The functional characterization of recombinant PAFC provided evidence for a promising new molecule in anti-Candida therapy. The thermotolerant PAFC killed planktonic cells and reduced the metabolic activity of sessile cells in pre-established biofilms of two Candida albicans strains, one of which was a fluconazole-resistant clinical isolate showing higher PAFC sensitivity than the fluconazole-sensitive strain. Candidacidal activity was linked to severe cell morphology changes, PAFC internalization, induction of intracellular reactive oxygen species and plasma membrane disintegration. The lack of hemolytic activity further corroborates the potential applicability of PAFC in clinical therapy.
\end{abstract}

Keywords: Penicillium chrysogenum antimicrobial protein C; PAFC; exudate; Candida albicans; reactive oxygen species; plasma membrane permeabilization; cell death 


\section{Introduction}

The global incidence of fungal infections and the increasing resistance development pressure the medical community to find alternatives to the currently used antimycotics. It is estimated that over 300 million patients are affected by fungal infections and around 1.6 million deaths are caused by fungal diseases annually [1].

The most prevalent human pathogenic yeasts which can cause life-threatening infections are the Candida species, Candida albicans being the most prevalent one, but the incidence of infections caused by non-albicans Candida species (NAC) is also increasing [2,3]. C. albicans can cause a wide range of human infections, from recurring superficial nail, skin and mucosal infections to severe and life-threatening systemic mycoses [4].

A limited number of licensed antifungal agents are available primarily due to the low number of drug targets that are unique in fungi. This poses a challenge in the prevention and treatment of fungal infections. Prolonged exposure to the currently available antifungal drugs can cause severe side-effects and permanently damage the patients organs [5]. Current anti-Candida therapies include azoles, echinocandins or amphotericin B, however the intensive application of azoles in clinical treatment facilitates resistance development in these pathogens [6]. It is of utmost importance to identify new antifungal agents with mechanisms of action that differ from those of existing drugs, with targets that are unique to the fungal cell in order to be safely applicable to humans, and with low risk for resistance development.

A promising source of new anti-Candida compounds are antimicrobial proteins (AMPs), secreted by filamentous fungi of the class Eurotiomycetes [7]. One representative of this group, the antibiotic producer Penicillium chrysogenum, harbors three genes that code for two well-characterized AMPs-the P. chrysogenum antifungal protein (PAF) and antifungal protein B (PAFB) [8] - and a third putative antifungal protein C (PAFC, Pc21g12970) [9]. Amino acid (aa) similarity analysis revealed that PAFC is identical to the Pc-Arctin from an artic P. chrysogenum A096 isolate [10] and shares high similarity with the "bubble protein" (BP) from Penicillium brevicompactum [11] and the Penicillium expansum antifungal protein PeAfpC [12]. PAFC, Pc-Arctin, BP and PeAfpC belong to the so-called "BP cluster", which is named according to the first reported protein (BP) of this group. They are phylogenetically different to the members of the PAF cluster that includes the two related P. chrysogenum AMPs, PAF and PAFB $[11,13]$. The members of the BP cluster, however, are still less studied in terms of antifungal activity and potential for application compared to other AMPs from filamentous ascomycetes.

The aim of this study was to characterize the antimicrobial protein PAFC of P. chrysogenum strain Q176, a descendant of the original penicillin producer strain NRRL1951 and the ancestor of the Wis54-1255 strain whose genome was sequenced [14,15]. For simplicity, we refer in the following to P. chrysogenum Q176 as P. chrysogenum. We present an in silico analysis of the structural properties of PAFC and, we report for the first time the gene expression of a BP cluster protein in submersed cultures and surface colonies, its recombinant production and purification in high yield, and its growth inhibition efficacy against the opportunistic human pathogen C. albicans. We have included in the analysis the fluconazole sensitive C. albicans strain CBS 5982-referred in the following as C. albicans ${ }^{\text {fluS }}$-and the fluconazole resistant clinical isolate 27700 (C. albicans ${ }^{f l u R}$ ) [16]. We report that both strains were susceptible to PAFC, with C. albicans ${ }^{f l u R}$ being more sensitive than C. albicans ${ }^{f l u S}$. We have determined the antifungal efficacy of PAFC against planktonic and sessile cells, the cellular uptake of PAFC, the induction of intracellular reactive oxygen species (iROS) and the permeabilization of the plasma membrane to the impermeable cell death indicating dye propidium iodide (PI). The anti-Candida efficacy, thermotolerance and absence of hemolytic activity suggest that PAFC may be a potential candidate next generation antifungal drug that is also effective against azole-resistant $C$. albicans strains. 


\section{Materials and Methods}

\subsection{In Silico Structural Prediction of PAFC}

In silico structural prediction was done based on the hypothetical protein annotated as Pc21g12970 (National Center for Biotechnology Information (NCBI), accession number XP_002568323) in Penicillium rubens Wisconsin 54-1255, which is a descendent of P. chrysogenum Q176 [14,15]. Full-length protein aa sequence was submitted to the I-Tasser server [17] for prediction of the secondary and tertiary protein structure. The crystal structure of the P. brevicompactum BP (PDB ID: 1uoy.pdb) was used as template without alignment, due to high primary structure similarity. The resulting model was chosen based on the Z-score and quality was energy minimized and refined with the ModRefiner [17]. The reliability of the calculated model was evaluated in Ramachandran plot analysis using a RAMPAGE server [18]. The disulfide bond pattern was predicted with Disulfind [19]. To evaluate the reliability of the predicted disulfide bond pattern, the distance between the bonded cysteine residues was analyzed by X-walk [20] using the BP bond pattern as template. Protein model visualization was performed with UCSF ChimeraX software [21]. Alignment of PAFC, PeAfpC and BP was realized with Jalview 2 [22] and sequence colored according to ClustalX. The percent identity matrix between these three proteins was calculated with ClustalW2 Multiple Sequence Alignment tool [23]. The physicochemical properties of PAFC were determined with GRAVY calculator (available online: www.gravy-calculator.de), ProtParam tool (available online: www.web.expasy.org), and ProteinCalculator v3.4 (available online: www.protcalc.sourceforge.net).

\subsection{Strains and Growth Conditions}

Fungal strains used in this study are listed in Supplementary Materials, Table S1 and the composition of the media is described in Supplementary Materials, Table S2. For the generation of conidia, $P$. chrysogenum Q176 was grown on $1 \times P c \mathrm{MM}$ for $96 \mathrm{~h}$ at $25^{\circ} \mathrm{C}$. Conidia were harvested and washed in spore buffer $(0.9 \% \mathrm{NaCl}(w / v), 0.01 \%$ Tween $(v / v))$ before use. Germlings were generated by growing conidia in $1 \times P c \mathrm{MM}$ at $25^{\circ} \mathrm{C}$ in static culture until the germ tubes were twice the length of the conidia diameter $(11 \mathrm{~h})$. For $P$. chrysogenum submersed shaking cultures $200 \mathrm{~mL} 1 \times P c \mathrm{MM}$ was inoculated with $2 \times 10^{8}$ spores and cultivated for up to $96 \mathrm{~h}$ at $25^{\circ} \mathrm{C}$ and $200 \mathrm{rpm}$. Synchronized surface cultures were generated on $1 \times P c M M$, containing $1.5 \%(w / v)$ agar at $25^{\circ} \mathrm{C}$ as described in Hegedüs et al., 2011 [24]. For the generation of fungal exudates, $5 \mu \mathrm{L}$ aliquots containing $1 \times 10^{6}$ P. chrysogenum conidia were point inoculated on $1 \times P c \mathrm{MM}$ or double-concentrated PcMM $(2 \times P c \mathrm{MM})$, containing $1.5 \%(w / v)$ agar. The surface cultures were grown for up to $144 \mathrm{~h}$ at $25^{\circ} \mathrm{C}$ in a box lined with wet paper towels. Single colonies of Candida strains grown on potato dextrose broth (PDB) agar plates (Sigma-Aldrich, St. Louis, MO, USA) were used to inoculate $10 \mathrm{~mL}$ ten-fold diluted PDB $(0.1 \times \mathrm{PDB})$. After overnight cultivation at $30^{\circ} \mathrm{C}$ and $160 \mathrm{rpm}$ the cells were washed in $0.1 \times$ PDB before experimental use.

\subsection{Detection of PafC $m$ RNA}

The expression of pafC was investigated in conidia, germlings, and mycelia of submersed and synchronized surface cultures of P. chrysogenum. Total RNA was extracted from cells with TRI Reagent (Sigma-Aldrich, St. Louis, MO, USA) according to the manufacturer's instruction. Ten $\mu g$ RNA per lane were loaded onto a $1.2 \%(v / v)$ formaldehyde gel, electrophoresed and blotted onto a Hybond $\mathrm{N}$ membrane (Amersham Biosciences, Little Chalfont, UK). The pafC transcripts were detected with a digoxigenin-labelled hybridization probe (Roche, Basel, Switzerland) amplified by PCR (Table S3) from pafC cDNA using pafC specific primers (Table S4).

\subsection{Detection of Native PAFC}

Submersed cultures of $P$. chrysogenum were prepared as described above and the supernatant was used for Western blot analysis at different time points. Fungal exudates, the liquid secreted 
underneath the fungal colony and the droplets on top of the colony, were harvested as described in Supplementary Materials (experimental procedures; Figure S1) after $120 \mathrm{~h}$ of incubation. Samples $(20 \mu \mathrm{L}$ per lane) were loaded onto a 18\% (w/v) SDS-polyacrylamide gel, electrophoresed and Western blotting performed as described (Supplementary Materials, experimental procedures). PAFC was detected using rabbit anti-PeAfpC serum (1:2500) [12]. PAF and PAFB in the exudate were detected using IgG purified rabbit anti-PAF serum (1:500) [25] and rabbit anti-PAFB serum (1:1000) [9], respectively (Supplementary Materials, experimental procedures).

\subsection{Generation of Recombinant PAFC}

Recombinant PAFC was prepared using a P. chrysogenum-based expression system [26]. The cloning of expression vector pSK275_pafC (Figure S2) and transformation into the P. chrysogenum $\Delta$ paf mutant strain [26] are described in Supplementary Materials (experimental procedures). The strain with the highest PAFC content in the culture broth was named P. chrysogenum ${ }^{\text {EpafC }}$ and used for large-scale expression. The cell-free supernatant was processed as described previously [26] with minor modification. The $\mathrm{pH}$ of the supernatant was adjusted to 4.0 with $1 \mathrm{M}$ citric acid before it was filter sterilized, degassed and loaded onto a BioPro S30 cation exchange column (YMC CO. LTD, Kyoto, Japan). The column was washed with $0.1 \mathrm{M}$ equilibration buffer $(0.1 \mathrm{M}$ citrate buffer $\mathrm{pH} 4$, $0.5 \mathrm{M}$ EDTA, $25 \mathrm{mM} \mathrm{NaCl})$ and PAFC was eluted with $0.1 \mathrm{M}$ elution buffer $(0.1 \mathrm{M}$ citrate buffer $\mathrm{pH} 4$, $100 \mathrm{mM} \mathrm{NaCl}$ ). Fractions containing the protein peak were checked for PAFC content and purity on a $18 \%(w / v)$ SDS-polyacrylamide gel and by silver staining. The pure PAFC containing fractions were concentrated and dialyzed against $\mathrm{dd}_{2} \mathrm{O}$ using a Vivaspin $₫ 500$ device ( $3 \mathrm{kDa}$ MWCO; GE Healthcare, Chicago, IL, USA). The identity of PAFC was verified by electrospray ionization mass spectroscopy (ESI-MS) (Protein Micro-Analysis Facility; Biocenter, Medical University of Innsbruck) and the purity of the protein confirmed by reverse-phase high-performance liquid chromatography (RP-HPLC). The RP-HPLC run was performed on a Phenomenex Jupiter $10 \mu \mathrm{M}$ C18 $300 \AA$ column using the following eluent system: (A) $0.1 \%(v / v)$ trifluoroacetic acid (TFA); (B) $80 \%(v / v)$ acetonitrile and $0.1 \%$ $(v / v)$ TFA. A linear gradient of $15-40 \%$ (B) in $25 \mathrm{~min}$ was applied at a flow rate of $1.0 \mathrm{~mL} \cdot \mathrm{min}^{-1}$.

\subsection{Determination of Anti-Candida Activity}

\subsubsection{Broth Microdilution Assays}

For determination of the inhibitory concentration that reduces growth $\geq 90 \%$ (IC $\left.\mathrm{C}_{90}\right), 100 \mu \mathrm{L}$ of yeast cells $\left(1 \times 10^{4} \mathrm{~mL}^{-1}\right)$ were mixed with $100 \mu \mathrm{L}$ of PAFC in increasing concentrations $(0-20 \mu \mathrm{M})$ in $0.1 \times \mathrm{PDB}$ in 96-well, flat-bottom microtiter plates (Thermo Scientific, Waltham, MA, USA). Amphotericin B, nystatin and fluconazole were purchased from Sigma-Aldrich (St. Louis, MO, USA) and tested in a concentration range of $0-125 \mu \mathrm{g} \mathrm{mL}^{-1}$. To study the effect of serum and ions on the antifungal activity, increasing concentrations of heat-inactivated fetal calf serum (5-15\%) and $\mathrm{NaCl}, \mathrm{CaCl}_{2}$ and $\mathrm{MgCl}_{2}$ $(1.25-10 \mathrm{mM})$ were included in broth microdilution assays together with $1 \times \mathrm{IC}_{90}$ PAFC and C. albicans in $0.1 \times$ PDB as described above. C. albicans cells exposed to the supplements without PAFC served as controls. The thermal tolerance of PAFC was studied by incubating the protein for $5 \mathrm{~min}$ at $95^{\circ} \mathrm{C}$ and determining the antifungal activity immediately after cooling to $25^{\circ} \mathrm{C}$. PAFC that had not been exposed to serum, ions or heat served as full-activity control. The optical density $\left(\mathrm{OD}_{620 \mathrm{~nm}}\right)$ was determined after static cultivation for $24 \mathrm{~h}$ at $30^{\circ} \mathrm{C}$ using a multi-mode microplate reader (FLUOstar Omega, BMG Labtech, Ortenberg, Germany) operating in well-scanning mode. All assays included a blank (medium without cells) and an untreated growth control representing 100\% growth. All experiments were done using technical triplicates and repeated at least twice.

\subsubsection{Determination of Colony Forming Units (CFU)}

To determine the killing efficacy of PAFC, $C$. albicans planktonic cells from an overnight culture were diluted to $2 \times 10^{5}$ cells.mL $\mathrm{mL}^{-1}$ in $0.1 \times \mathrm{PDB}$ and treated with $1 \times \mathrm{IC}_{90}(2.5 \mu \mathrm{M}), 2 \times \mathrm{IC}_{90}(5 \mu \mathrm{M})$ or 
$4 \times \mathrm{IC}_{90}(10 \mu \mathrm{M})$ PAFC for $1 \mathrm{~h}, 8 \mathrm{~h}$ and $24 \mathrm{~h}$ at $30^{\circ} \mathrm{C}$ under continuous shaking (160 rpm). Untreated cells were used as a growth control. Cells were collected by centrifugation, resuspended in $1 \mathrm{~mL}$ $0.1 \times \mathrm{PDB}$ and a serial dilution up to $10^{-6}$ was prepared. From each dilution, $100 \mu \mathrm{L}$ were streaked onto $2 \%(w / v)$ PDB agar plates and incubated at $30{ }^{\circ} \mathrm{C}$ for $24 \mathrm{~h}$ before the colony forming units (CFU) were counted. The CFU of the untreated control was set at $100 \%$. All experiments were done using technical quadruplicates and repeated twice.

To evaluate the activity of PAFC on sessile cells of $C$. albicans, biofilm formation was induced by distributing $100 \mu \mathrm{L}$ aliquots of a cell suspension $\left(1 \times 10^{6}\right.$ cells $\cdot \mathrm{mL}^{-1}$ in $\left.0.1 \times \mathrm{PDB}\right)$ in the wells of a 96-well, flat-bottom microtiter plate (Thermo Scientific, Waltham, MA, USA) followed by a static incubation for $24 \mathrm{~h}$ at $30{ }^{\circ} \mathrm{C}$. The resulting biofilm was checked microscopically for cell attachment and pseudo-hyphae formation before treatment. The biofilm was gently washed with $0.1 \times$ PDB before $100 \mu \mathrm{L}$ of $1 \times \mathrm{IC}_{90}(2.5 \mu \mathrm{M})$ and $10 \times \mathrm{IC}_{90}(25 \mu \mathrm{M})$ PAFC was added in respective wells. For the negative control, the cells were incubated with $0.1 \times \mathrm{PDB}$ and for the positive control the cells were exposed to $10 \mu \mathrm{g} \cdot \mathrm{mL}^{-1}$ amphotericin B. After $24 \mathrm{~h}$ of incubation, the biofilm was disrupted by vigorous pipetting, and $10 \mu \mathrm{L}$ of the detached cells were mixed with $40 \mu \mathrm{L}$ fresh $0.1 \times$ PDB. Serial dilution of this sample up to $10^{-6}$ were made and $100 \mu \mathrm{L}$ streaked out onto $2 \%(w / v)$ PDB agar plates and incubated at $30^{\circ} \mathrm{C}$ for $24 \mathrm{~h}$ for CFU determination. The CFU of the untreated control was set at $100 \%$. All experiments were conducted using technical triplicates and repeated twice.

\subsection{Scanning Electron Microscopy (SEM)}

C. albicans cells $\left(5 \times 10^{5}\right.$, diluted in $\left.0.1 \times \mathrm{PDB}\right)$ from an overnight liquid culture were incubated with $1 \times \mathrm{IC}_{90}$ PAFC for $1 \mathrm{~h}, 12 \mathrm{~h}$, and $24 \mathrm{~h}$ at $30^{\circ} \mathrm{C}$ under continuous shaking at $160 \mathrm{rpm}$. Untreated cells were used as a negative control. Samples were washed, resuspended in phosphate buffered saline (PBS) and $8 \mu \mathrm{L}$ samples spotted onto a silicon disc coated with $0.01 \%(w / v)$ poly-L-lysine (Merck Millipore, Billerica, MA, USA). Cells were fixed with $2.5 \%(v / v)$ glutaraldehyde and $0.05 \mathrm{M}$ cacodylate buffer (pH 7.2) in PBS overnight at $4{ }^{\circ} \mathrm{C}$. The discs were washed twice with PBS and dehydrated with a graded ethanol series $\left(30 \%, 50 \%, 70 \%, 80 \%, 100 \%\right.$ ethanol $(v / v)$, for $1.5 \mathrm{~h}$ each at $\left.4{ }^{\circ} \mathrm{C}\right)$. Samples of untreated cells served as negative control. The samples were dried with a critical point dryer, followed by $12 \mathrm{~nm}$ gold coating (Quorum Technologies, Laughton, East Sussex, UK) and observed under a JEOL JSM-7100F/LV scanning electron microscope (JEOL Ltd., Tokyo, Japan).

\subsection{Fluorophore-Labeling of PAFC}

For visualization in uptake studies PAFC was labeled with the green fluorophore BODIPYTM FL EDA (Bd) (Invitrogen, Carlsbad, CA, USA) as described previously [27]. In brief, $0.4 \mathrm{mM}$ PAFC was labeled with $10 \mathrm{mM}$ Bd in the presence of $10 \mathrm{mM}$ EDAC and $5 \mathrm{mM}$ Sulfo-NHS (Invitrogen, Carlsbad, CA, USA) in $100 \mathrm{M}$ MES-buffer ( $\mathrm{pH}$ 4.5). The reaction mixture was incubated with continuous shaking at $200 \mathrm{rpm}$ overnight at $25^{\circ} \mathrm{C}$ in the dark. The labeled AMP (PAFC-Bd) was dialyzed against $\mathrm{ddH}_{2} \mathrm{O}$ to remove excess $\mathrm{Bd}$ and concentrated using AmiconßUltra centrifugal filters ( $3 \mathrm{kDa} \mathrm{MWCO}$; Merck Millipore, Burlington, MA, USA). The antifungal activity of PAFC-Bd was tested by broth microdilution assay as described above.

\subsection{Confocal Laser Scanning Microscopy (CLSM)}

Candida cells adjusted to $2 \times 10^{5}$ cells. $\mathrm{mL}^{-1}$ in $0.1 \times \mathrm{PDB}$ were treated with $1 \times \mathrm{IC}_{90}$ PAFC-Bd $(2.5 \mu \mathrm{M})$ for $3 \mathrm{~h}$ and $6 \mathrm{~h}$ at $30^{\circ} \mathrm{C}$ under continuous shaking at $160 \mathrm{rpm}$. Untreated cells were used as negative control. Samples were washed with PBS and stained consecutively with $5 \mu \mathrm{gL}^{-1} \mathrm{PI}$ (Sigma-Aldrich, St. Louis, MO, USA) and $5 \mu \mathrm{g} \cdot \mathrm{mL}^{-1}$ calcofluor white (CFW) (Sigma-Aldrich, St. Louis, MO, USA) for 10 min at room temperature in the dark. After washing with PBS, samples were mounted on a glass slide, covered with $2 \%(w / v)$ agar slices and observed with an Olympus Fluoview FV 1000 confocal laser microscope with $60 \times$ magnification objective (Olympus, Shinjuku, Japan). A $488 \mathrm{~nm}$ laser was used for excitation. The excitation and emission wavelengths were $380 \mathrm{~nm}$ and $475 \mathrm{~nm}$ 
for CFW, $504 \mathrm{~nm}$ and $512 \mathrm{~nm}$ for PAFC-Bd and $535 \mathrm{~nm}$ and $617 \mathrm{~nm}$ for PI, respectively. Sequential scanning was used to avoid crosstalk between the fluorescent dyes.

\subsection{Fluorescence Activated Cell Sorting (FACS)}

Candida cells diluted to $2 \times 10^{5}$ cells $\cdot \mathrm{mL}^{-1}$ in $0.1 \times \mathrm{PDB}$ were exposed to $1 \times \mathrm{IC}_{90}$ PAFC for $1 \mathrm{~h}$, $8 \mathrm{~h}$ and $24 \mathrm{~h}$ at $30^{\circ} \mathrm{C}$ under continuous shaking at $160 \mathrm{rpm}$. Untreated cells were used as negative control and $70 \%(v / v)$ EtOH treated cells as positive control for PI staining. The cells were washed in PBS, collected by centrifugation at $11,000 \times g$ for $5 \mathrm{~min}$ and stained with $5 \mu \mathrm{g} \cdot \mathrm{mL}^{-1}$ PI for $10 \mathrm{~min}$ at room temperature. PI positive cells were counted by a FlowSight imaging flow cytometer (Amins, Merck Millipore, Billerica, MA, USA) with at least 1000 cells were counted per run. For data analysis, the Image Data Exploration and Analysis software (IDEAS; Amins, Millipore, Billerica, MA, USA) was applied. Gates for the data analyses were established according to the unstained control. Experiments were performed using independent triplicates.

\subsection{Hemolytic Activity}

The hemolytic potential of PAFC was evaluated on Columbia blood agar plates (VWR, Randnor, PA, USA). Sterile filter discs (Ø6 mm) were put onto agar plates and loaded with $10 \mu \mathrm{L}$ aliquots containing $13 \mu \mathrm{g}$ PAFC. Sterile water and 20\% (v/v) Triton X-100 (10 $\mu \mathrm{L}$ each) served as controls. Plates were incubated at $37^{\circ} \mathrm{C}$ for $24 \mathrm{~h}$ before documentation.

\subsection{Statistical Analysis}

Data analyses were conducted with Microsoft Excel (2016, Version 16.16.16) software (Microsoft, Redmond, WA, USA). For the calculation of significant differences between the data obtained from treated samples $v$ s. the untreated controls, a two-sample Student's $t$-test was applied. $p$-values of $\leq 0.05$ were considered as significant and $p$-values of $\leq 0.005$ were considered as highly significant.

\subsection{Image Processing}

Images were processed and edited with Axiovision (Carl Zeiss GmbH, Oberkochen, Germany), Fiji [28], GNU Image Manipulation Program (GIMP, version 2.8.10) and Microsoft Power Point (Microsoft Corp.).

\section{Results}

\subsection{In Silico Prediction of the PAFC Structure}

The alignment of the pre-mature PAFC pre-pro protein sequence with that of PeAfpC from P. expansum and BP from P. bevicompactum revealed $85.2 \%$ and $70.1 \%$ identity, respectively (Figure S3). The mature PAFC is 64 aa long, has a predicted molecular mass of $6630 \mathrm{Da}$ (assuming all cysteines in reduced form) and is $100 \%$ identical to the Pc-Arctin of the arctic isolate P. chrysogenum A096 [10]. It has $82.8 \%$ and $79.7 \%$ identity to the mature form of PeAfpC and BP, respectively (Figure S3). All three proteins possess two putative levomeric $\gamma$-core motifs $\left(\mathrm{CX}_{3-9} \mathrm{CXGX}_{1-3}\right)$ [29], which are conserved among the ascomycetous AMPs of the BP cluster [13]. One of them-positioned in the center of PAFC (CDRTGIVECKG) - is highly conserved, and the second, shorter one with lower homology resides near the C-terminus (CGGASCRG) (Figure 1A and Figure S3).

The in silico prediction of the PAFC tertiary structure gave a model showing high fold similarity to the BP of P. brevicompactum [30]. The Ramachandran plot of the model showed $95.2 \%$ of the aa positioned in energetically favored regions and three in the allowed regions (4.8\%) (Figure S4). The PAFC model exhibits five antiparallel $\beta$-strands ( $\beta 1-\beta 5)$, spanning His26-Cys28 ( $\beta 1)$, Gly34-Lys39 ( $\beta 2)$, Lys42-Asp48 ( $\beta 3)$, Arg55-Val57 ( $\beta 4)$ and Gly60-Arg63 ( $\beta 5)$, which are connected by four loops (L1-L4). The protein model shows an $N$-terminal three stranded $\beta$-sheet $(\beta$-sheet 1$)$ with an $N$-terminal extended structure and a $C$-terminal two stranded $\beta$-sheet $(\beta$-sheet 2$)$. The $\gamma$-core motif in the protein 
center (Cys30-Lys39) encompasses L1 and $\beta 2$, and the shorter $\gamma$-core motif (Cys49-Gly56) contains a part of L3 and $\beta 4$ (Figure 1B). As already shown for the BP protein [11] the $\beta$-pleated structure of PAFC is stabilized by four intramolecular disulfide bonds that are formed between the eight cysteine residues. The predicted disulfide bond pattern (Cys 3/30, Cys 18/38 Cys 28/54, Cys 49/64) of PAFC follows the abcabdcd pattern of the BP [30]. The disulfide bonds Cys 3/30 and Cys 18/38 connect the $\beta$-sheet 1 to the $\mathrm{N}$-terminal extended region, while Cys 28/54 and Cys 49/64 connect $\beta$-sheet 1 with $\beta$-sheet 2 (Figure 1C).

A

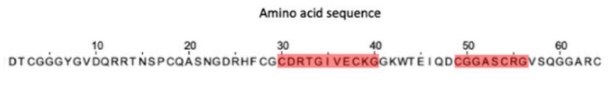

B

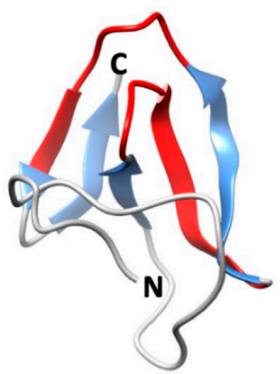

C

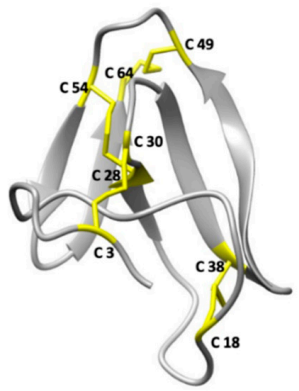

D
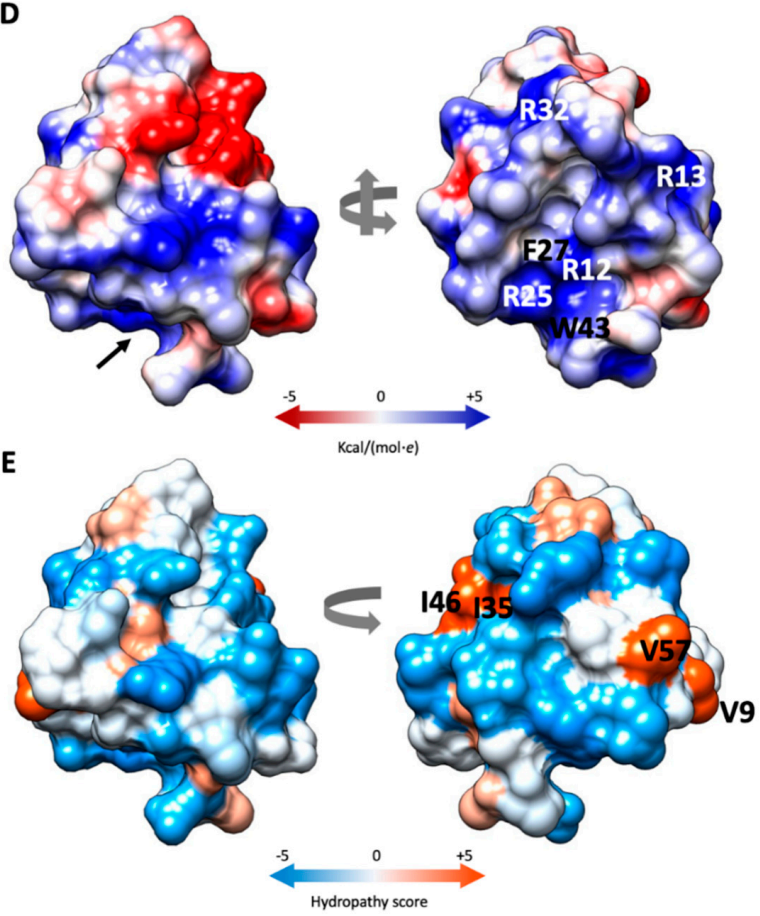

Figure 1. Predicted structure of PAFC. (A) Amino acid sequence (aa) of PAFC with the two predicted $\gamma$-core motifs highlighted in red. (B) Ribbon representation of PAFC in UCSF Chimera protein visualization and analysis software [21] depicting the structure of the $\beta$-strands (blue) and location of the two $\gamma$-cores (red), the $\mathrm{N}$ - and C-terminus is indicated. (C) Disulfide bonding of PAFC is shown with yellow sticks. (D) Surface representation of PAFC in two orientations colored according to electrostatic potential (blue: electropositive, red: electronegative). The model depicted on the right side visualizes the "mouth-like" cavity indicated by a black arrow in the left model. The basic aas surrounding the opening and the aa forming the funnel base are indicated. (E) Distribution of hydrophobic and hydrophilic patches on the surface of PAFC in two orientations colored according to the Kyte-Doolittle scale (blue: hydrophilic, orange: hydrophobic). The aas forming the hydrophobic patches are indicated in the model on the right. 
Analysis of the electrostatic surface distribution according to Coulomb's law in UCSF Chimera software [21] indicated that the putative PAFC structure has a cavity similar to BP [30]. The opening of this "mouth-like" structure is dominated by basic aas (Arg12, Arg13, Arg25, Arg32) that are in highly conserved positions in BP and PAFC, with Arg12, Phe27 and Trp43 form the funnel base (Figure 1D). The opposite side has two negatively charged patches, a smaller one consisting of Asp24 and Glu37, and a bigger one, consisting of Asp31, Asp48 and Glu45 (Figure 1D; Supplementary Materials, Video S1). According to the Kyte-Doolittle scale [31], PAFC shows an amphipathic surface with the aas Val9, Ile35/Ile46 and Val57 forming three hydrophobic patches (Figure 1E; Supplementary Materials, Video S2).

\subsection{Expression of PAFC in P. chrysogenum}

Northern blot experiments indicated that the expression of the PAFC encoding gene (pafC) peaked after $72 \mathrm{~h}$ of cultivation under standard submersed conditions (Figure 2A). Expression of pafC was also detected in synchronized P. chrysogenum surface cultures and correlated with the onset of conidiation (Figure S5), with gene expression reaching its maximum after $36 \mathrm{~h}$ of incubation (Figure 2B). No pafC expression was detected in conidia or 11-h-old germlings. These results imply that PAFC is produced under submersed and surface growth conditions in P. chrysogenum. To demonstrate PAFC in the fungal culture broth, we performed a Western blot analysis (Figure 2C) probed with a rabbit polyclonal antibody generated against the PAFC-related PeAfpC [12]. This antibody recognized the purified recombinant PAFC (Figure S6) and did not bind to the purified recombinant PAF or PAFB (Figure 3B, upper panel). A faint band with the molecular weight corresponding to mature native PAFC was detected in the crude fermentation broth of submersed cultures after $72 \mathrm{~h}$ and $96 \mathrm{~h}$ of cultivation (Figure 2C). However, the anti-PeAfpC antibody also bound to secreted proteins with molecular weight $>6.6 \mathrm{kDa}$ in the crude supernatant. This may be due to (I) the polyclonal character of the anti-PeAfpC antibody [12] and (II) the low PAFC amount in the culture broth, which necessitated a long development time to obtain a detectable signal intensity for the PAFC specific band.

A

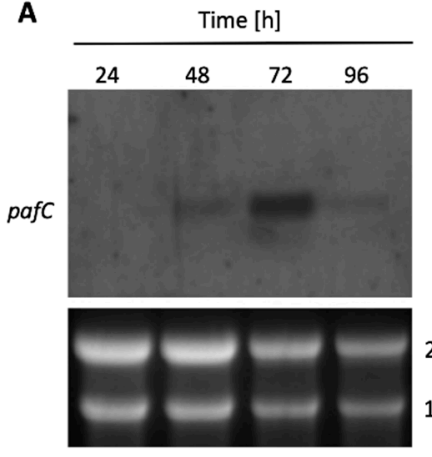

B

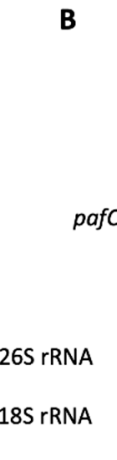

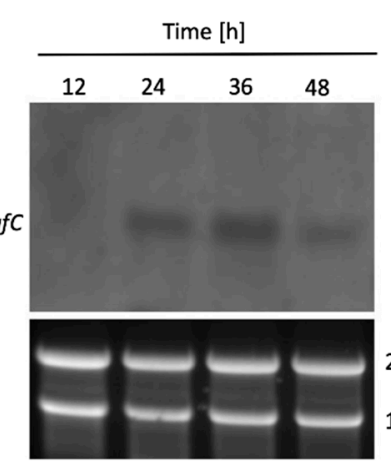

C

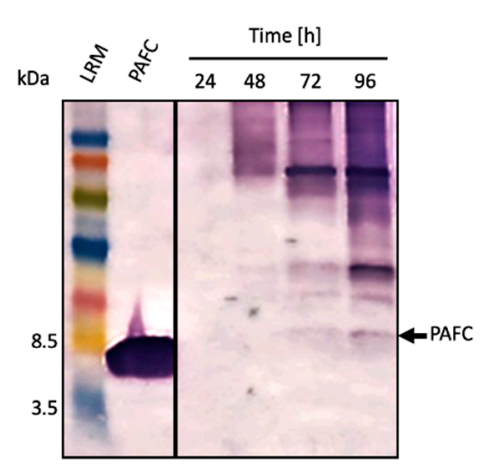

Figure 2. Expression of the PAFC encoding gene and protein. Total RNA was extracted from (A) mycelium grown in submersed and (B) synchronized surface cultures up to $96 \mathrm{~h}$. Ten $\mu \mathrm{g}$ of total RNA was loaded per lane on a 1.2\% denaturing agarose gel, blotted onto a nylon membrane and hybridized with a pafC specific digoxigenin-labelled PCR probe (upper panels). Ethidium bromide-stained $26 \mathrm{~S}$ and 18S rRNA provide loading controls (lower panels). (C) For Western blot analysis, $20 \mu \mathrm{L}$ of the cell free supernatant from submersed cultures was loaded per lane, size fractionated on an $18 \%(w / v)$ SDS-polyacrylamide gel and transferred onto a nitrocellulose membrane. A polyclonal antibody generated against PeAfpC was used to probe for PAFC. Recombinant PAFC $(0.5 \mu \mathrm{g})$ was used as a control for antibody binding. The black arrow indicates PAFC (6.6 kDa). LRM, low range rainbow marker (GE Healthcare Life Sciences, Little Chalfont, UK). The molecular weight marker bands of $3.5 \mathrm{kDa}$ and $8.5 \mathrm{kDa}$ are indicated. 


\subsection{Expression of PAFC, PAF and PAFB in Fungal Exudates}

Seibold et al. (2011) [11] found the BP in exudates of P. brevicompactum surface cultures. This prompted us to check the droplets formed on the colony surface of P. chrysogenum grown on solid medium. These droplets emerged after $120 \mathrm{~h}$ of cultivation on colonies that had been point inoculated on solid P. chrysogenum minimal medium $(1 \times P c \mathrm{MM})$. On this medium the droplets formed a ring around the center of the P. chrysogenum colony (Figure 3A). These droplets originated from the fungal exudate that the colony secreted basally. The amount of liquid underneath the colony and the size of droplets could be augmented by cultivating $P$. chrysogenum on agar containing double-concentrated nutrients $(2 \times P c \mathrm{MM})$ (Figure 3A). Here the droplets accumulated on top of the colony. When the exudate that had formed underneath the colony after $96 \mathrm{~h}$ was harvested, no further droplets emerged on top of the colony with further incubation (Figure S1), indicating the same origin of the exudate and the droplets. After an extended incubation of $144 \mathrm{~h}$ the exudate had completely disappeared (Figure S1). PAFC was detected by Western blot analysis in both, the exudate formed underneath the colony and the droplets (Figure $3 \mathrm{~B}$ ). We also tested the samples for the presence of the other two P. chrysogenum AMPs and could detect PAF and PAFB by using polyclonal anti-PAF and anti-PAFB antibodies [9,25] (Figure 3B).

\section{A}

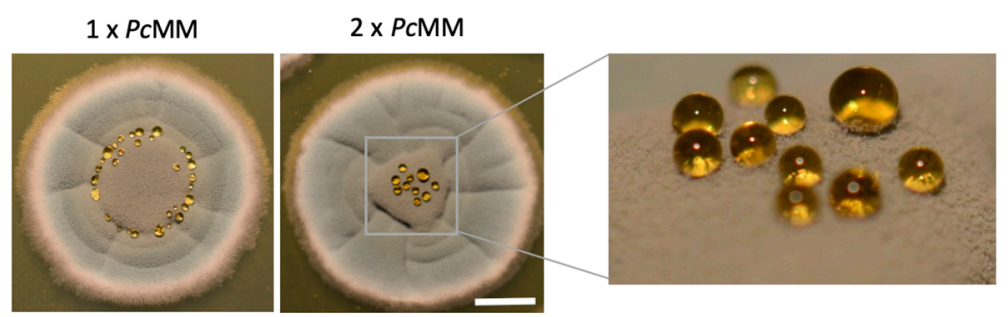

B

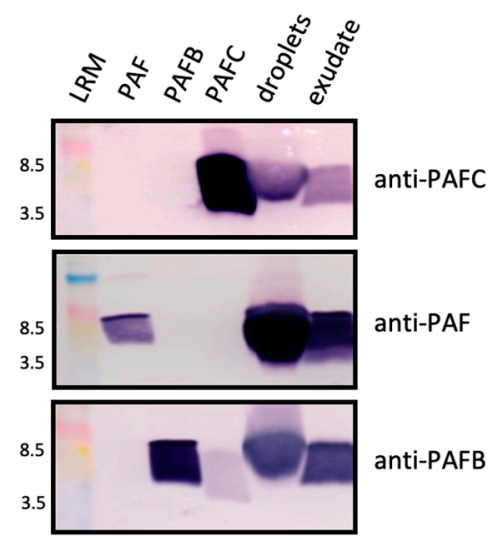

Figure 3. Detection of PAFC in P. chrysogenum exudate. (A) Droplet formation on P. chrysogenum surface cultures grown on $1 \times P c M M$ and $2 \times P c M M$ for $120 \mathrm{~h}$ at $25{ }^{\circ} \mathrm{C}$. Scale bar, $5 \mathrm{~mm}$. (B) For Western blot analysis, $20 \mu \mathrm{L}$ of droplets and exudate from cultures grown on $2 \times P c M M$ were loaded per lane, fractionated on an 18\% (w/v) SDS-polyacrylamide gel and transferred onto a nitrocellulose membrane. Polyclonal antibodies were used to detect PAFC, PAF and PAFB. As a control for antibody binding, $0.5 \mu \mathrm{g}$ of the respective recombinant protein (PAFC, PAF and PAFB) was loaded per lane. LRM, low range rainbow marker (GE Healthcare Life Sciences, Little Chalfont, UK). The molecular weight marker bands of $3.5 \mathrm{kDa}$ and $8.5 \mathrm{kDa}$ are indicated. 


\subsection{Bulk Production and Purification of Recombinant PAFC}

Figure 2C indicates that the amount of native PAFC in the supernatant of P. chrysogenum was insufficient for purification and further functional investigations. Therefore, we expressed recombinant PAFC using a P. chrysogenum-based expression system [26] by cloning pafC into the pSK275 vector between the strong paf promoter and the paf terminator sequence (Figure S2). The P. chrysogenum $\Delta$ paf strain transformed with linearized pSK275_pafC served as cell factory for PAFC expression [32,33]. The strain secreting the highest PAFC quantity (P. chrysogenum ${ }^{\text {EpafC }}$ ) was selected for protein production and PAFC was purified from $96 \mathrm{~h}$ cell culture supernatant by one-step cation-exchange chromatography (Figure S7A). A protein yield of up to $105 \pm 15 \mathrm{mg} \mathrm{L}^{-1}$ fermentation broth was obtained. RP-HPLC gave a single elution peak suggesting high purity of the sample (Figure S7B). The identity of PAFC was verified by ESI-MS. The detected mass of 6622 Da matched the predicted mass of oxidised PAFC which contains four disulfide bonds and lacks the pre-pro sequence (Figure S7C).

\subsection{Anti-Candida Activity of PAFC in Broth Microdilution Assays}

The recombinant PAFC was tested for anti-Candida activity in broth microdilution assays and the inhibitory concentration that reduces growth $\geq 90 \%\left(\mathrm{IC}_{90}\right)$ was determined (Table 1$)$. PAFC inhibited the growth of the Candida spp. tested (Table S1) at low $\mu \mathrm{M}$ concentrations, and the fluconazole sensitive $C$. albicans ${ }^{f l u S}$ and a fluconazole resistant clinical isolate $C$. albicans ${ }^{f l u R}$ exhibited the same PAFC sensitivity $\left(\mathrm{IC}_{90} 2.5 \mu \mathrm{M}\right.$ ) (Table 1 and Table S1). For comparison, we also tested the susceptibility of Candida spp. for the commonly used antifungal drugs fluconazole, amphotericin B and nystatin (Table 1). The C. albicans ${ }^{f l u R}$ strain still proliferated in the presence of the highest fluconazole concentration tested $\left(125 \mu \mathrm{g} \mathrm{mL} \mathrm{m}^{-1}\right)$ which confirmed its resistance against this common drug under the experimental conditions applied in this study.

Table 1. Inhibitory concentrations of PAFC and commonly used antifungal drugs reducing Candida spp. growth $\geq 90 \%\left(\mathrm{IC}_{90}\right)^{\S}$.

\begin{tabular}{ccccc}
\hline Microorganisms & PAFC & Fluconazole & Amphotericin B & Nystatin \\
\hline Candida albicansflus & $2.50(16.50)$ & $6.37(1.95)$ & $0.02(0.02)$ & $2.11(1.95)$ \\
Candida albicans $f l u R$ & $2.50(16.50)$ & $408.50(>125)$ & $1.05(0.97)$ & $0.53(0.49)$ \\
Candida glabrata & $0.15(0.99)$ & $12.78(3.91)$ & $0.03(0.03)$ & $0.53(0.49)$ \\
Candida guilliermondii & $3.12(20.59)$ & $1.60(0.49)$ & $0.06(0.06)$ & $1.06(0.98)$ \\
Candida krusei & $2.50(16.50)$ & $51.08(15.63)$ & $0.06(0.06)$ & $1.06(0.98)$ \\
Candida parapsilosis & $0.04(0.26)$ & $12.78(3.91)$ & $8.45(7.81)$ & $1.06(0.98)$ \\
\hline
\end{tabular}

$\S$ Candida spp. $\left(1 \times 10^{3}\right.$ cells $\left.\mathrm{mL}^{-1}\right)$ were grown in $0.1 \times \mathrm{PDB}$ for $24 \mathrm{~h}$ at $30^{\circ} \mathrm{C}$ under static conditions. $\mathrm{IC}_{90}$ was defined as PAFC concentration that inhibits growth $\geq 90 \%$ compared to the untreated control. $\mathrm{IC}_{90}$ values are given in $\mu \mathrm{M}$ ( $\mu \mathrm{g} \mathrm{mL} \mathrm{L}^{-1}$ in parenthesis).

\subsection{Impact of PAFC on C. albicans Biofilm}

We investigated the antifungal effect of PAFC on sessile cells of the most prevalent pathogen in this group using C. albicansfluS and C. albicans ${ }^{f l u R}$. A 24-h-old biofilm was treated with $1 \times \mathrm{IC}_{90}$ $(2.5 \mu \mathrm{M})$ and $10 \times \mathrm{IC}_{90}(25 \mu \mathrm{M})$ PAFC because biofilms are generally less accessible to antifungal compounds [34] and the established biofilm contains a higher cell number than the experiments performed with planktonic cells.

The survival of the sessile cells evaluated by CFU determination using a plating assay revealed that PAFC inhibited biofilm formation in a concentration dependent manner. Table 2 shows that the number of viable C. albicans ${ }^{f l u S}$ cells decreased significantly after the 24 -h treatment with $10 \times \mathrm{IC}_{90}$ PAFC compared to the untreated control. The C. albicans ${ }^{\text {fluR }}$ seemed to be more sensitive because a lower PAFC concentration $\left(1 \times \mathrm{IC}_{90}\right)$ significantly increased cell death. This was further aggravated when PAFC was applied at $10 \times \mathrm{IC}_{90}$. In both strains, however, a PAFC concentration as high as 
$10 \times \mathrm{IC}_{90}$ could not completely impede biofilm growth as shown with $10 \mu \mathrm{g} \mathrm{mL} \mathrm{L}^{-1}$ amphotericin B (no growth).

Table 2. Survival of Candida albicans sessile cells after $24 \mathrm{~h}$ treatment with PAFC determined by plating assay $\S$.

\begin{tabular}{|c|c|c|c|c|}
\hline \multirow{2}{*}{ Strain } & \multirow{2}{*}{ Untreated } & \multicolumn{2}{|c|}{ PAFC } & \multirow{2}{*}{ Amphotericin B $10 \mu \mathrm{g} \mathrm{mL}^{-1}$} \\
\hline & & $1 \times \mathrm{IC}_{90}$ & $10 \times \mathrm{IC}_{90}$ & \\
\hline Candida albicans ${ }^{f l u S}$ & $100 \pm 10.8$ & $83.4 \pm 3.0$ & $47.0 \pm 3.8^{*}$ & $0 \pm 0 * *$ \\
\hline Candida albicans ${ }^{f l u R}$ & $100 \pm 5.8$ & $48.1 \pm 2.2^{* *}$ & $28.1 \pm 4.5^{* *}$ & $0 \pm 0 * *$ \\
\hline
\end{tabular}

$\S$ Values of surviving cells are given in $\%$ CFU of the untreated control. ${ }^{*} p \leq 0.05$ and ${ }^{* *} p \leq 0.005$.

\subsection{Effect of PAFC on the C. albicans Cell Morphology}

The effect of PAFC on the morphology of C. albicans ${ }^{f l u S}$ and C. albicans ${ }^{f l u R}$ cells was evaluated using SEM. Untreated control cells exhibited a typical ovoid shape with budding sites and a smooth cell surface (Figure 4). In contrast, a $1 \mathrm{~h}$ treatment with $1 \times \mathrm{IC}_{90}$ PAFC $(2.5 \mu \mathrm{M})$ showed cells with a wrinkly surface and amorphous material on and between cells, which may indicate loss of osmotic pressure and leakage of cell contents, respectively. With longer incubation time (12 h), C. albicans cells showed severe signs of cell leakage and lost their ovoid shape. After $24 \mathrm{~h}$ morphologically intact C. albicans ${ }^{f l u S}$ cells were observed again, suggesting that some cells survived the treatment and resumed growth (Figure 4A). In contrast, C. albicansfluR cells still appeared severely damaged after $24 \mathrm{~h}$ of PAFC exposure (Figure 4B).
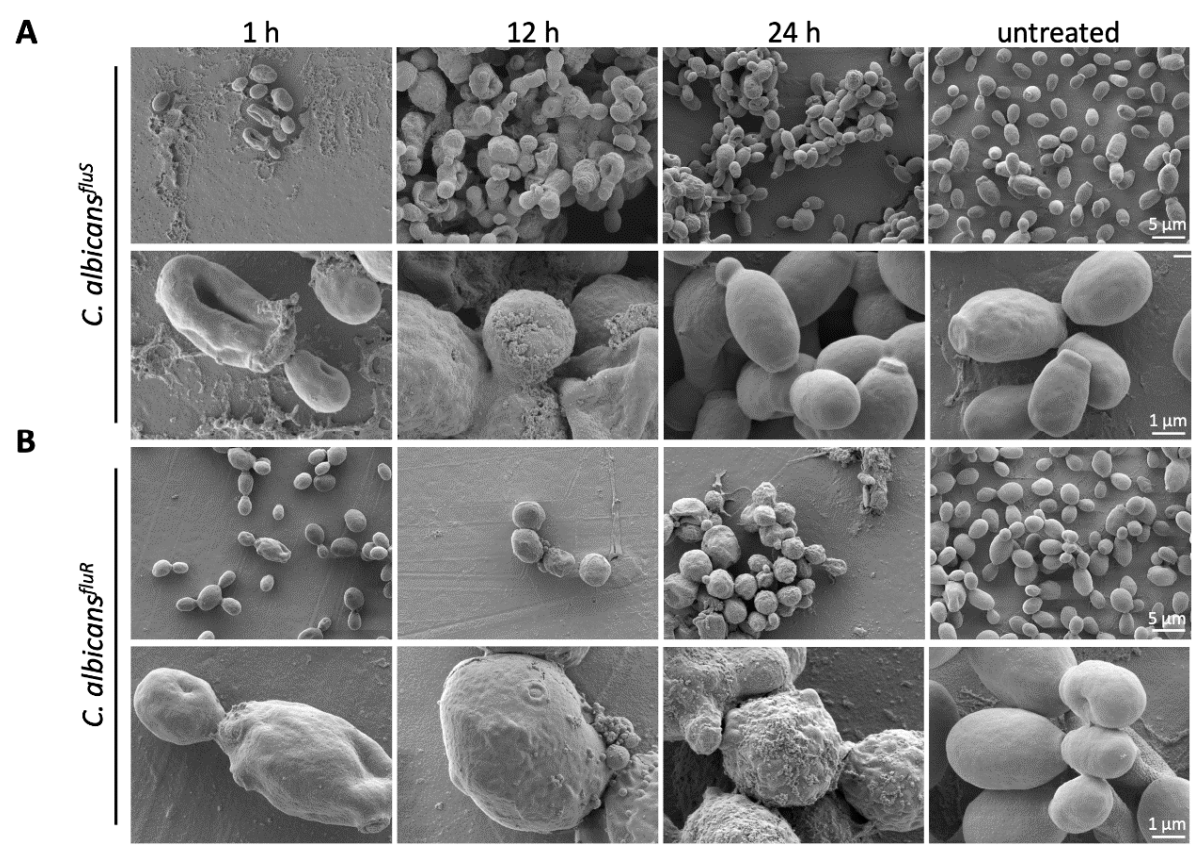

Figure 4. SEM analysis of the impact of PAFC on the C. albicans cell morphology. (A) C. albicans fluS $^{\text {and }}$ (B) C. albicans ${ }^{\text {fluR }}$ cells were incubated with $1 \times \mathrm{IC}_{90}(2.5 \mu \mathrm{M})$ PAFC or without PAFC (untreated) for $1 \mathrm{~h}, 12 \mathrm{~h}$ and $24 \mathrm{~h}$ at $30^{\circ} \mathrm{C}$ with continuous shaking at $160 \mathrm{rpm}$. One representative image out of three replicates is shown in overview and high magnification, respectively. Scale bars are indicated in the images.

\subsection{Cellular Localization of PAFC and Cell Death Induction}

To investigate whether PAFC interacts only with the outer cell layers (cell wall or plasma membrane) or enters the cytosol of the C. albicans cells we used CLSM to detect PAFC labeled with the green fluorophore BODIPY (PAFC-Bd). The fluorophore-labelling of PAFC had no adverse impact 
on its antifungal activity. The application of $2.5 \mu \mathrm{M}$ PAFC-Bd in a broth microdilution assay resulted in C. albicans growth inhibition of $98.6 \%$, which corresponded to the $\mathrm{IC}_{90}$ of PAFC. Co-staining with the membrane impermeant fluorescent cell death dye PI visualized cells that were killed by the interaction with PAFC-Bd. Cells were incubated for $3 \mathrm{~h}$ and $6 \mathrm{~h}$ to ensure that the PAFC-Bd specific fluorescence signal was intense enough for visualization. After $3 \mathrm{~h}$ PAFC-Bd attached to the outer layers of C. albicans fluS and this signal co-localized with the cell wall specific blue dye CFW (Figure 5A). Intracellular fluorescent patches (subcellular structures) indicated that PAFC-Bd was taken up by the cells without cell death induction (no PI signal). After $6 \mathrm{~h}$ the positively stained cells showed the PAFC-Bd signal dispersed in the whole cell (cytoplasm) that coincided with a strong intracellular PI signal, whereas cells exhibiting a PAFC-Bd signal that still localized in subcellular structures remained PI-negative (Figure 5A). A similar uptake and intracellular staining pattern with PAFC-Bd was observed with C. albicans ${ }^{f l u R}$ cells, although interaction of PAFC-Bd with cells could be detected only at $6 \mathrm{~h}$ of incubation (Figure 5B). Localization of PAFC-Bd with the nuclei was excluded when co-staining with the nuclei-specific dye Hoechst 33342 and imaged by fluorescence microscopy (Supplementary Materials, experimental procedures; Figure S8). Taken together, these qualitative microscopy-based data revealed that PAFC first enters sensitive cells before the plasma membrane is compromised and cell death is induced. This suggests that an intracellular PAFC target may exist.

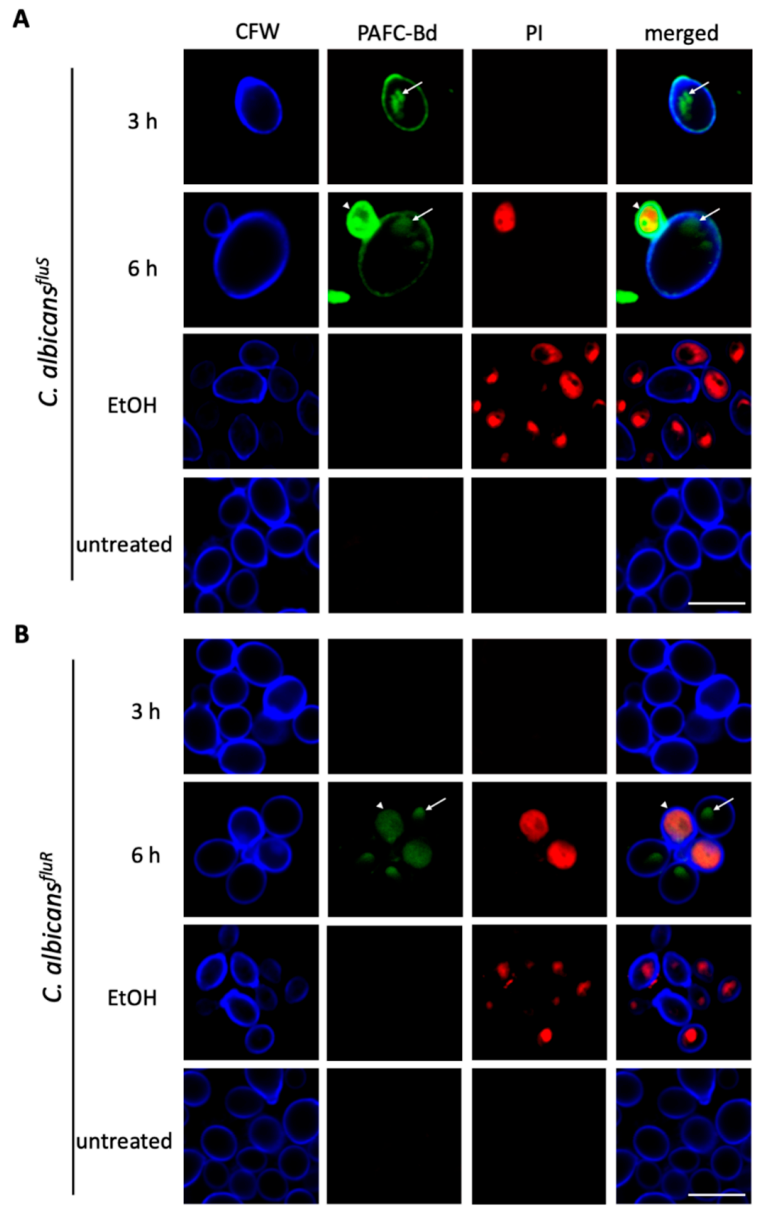

Figure 5. CLSM analysis of the cellular localization of PAFC and cell death induction. Cells of (A) C. albicans ${ }^{f l u S}$ and (B) C. albicans ${ }^{f l u R}$ were exposed to $1 \times \mathrm{IC}_{90}$ PAFC-Bd $(2.5 \mu \mathrm{M})$ for $3 \mathrm{~h}, 6 \mathrm{~h}$ and $12 \mathrm{~h}$ and then stained with calcofluor white (CFW, $5 \mu \mathrm{g} \mathrm{mL}^{-1}$ ) and propidium iodide (PI, $5 \mu \mathrm{g} \mathrm{mL}^{-1}$ ) for $10 \mathrm{~min}$. Control cells were left untreated. Sequential scanning was done for CFW (blue), PAFC-Bd (green) and PI (red) at 405, 488 and $543 \mathrm{~nm}$, respectively. White arrows indicate vacuoles, white arrowheads dead cells. One representative image out of three replicates is shown. Scale bar, $5 \mu \mathrm{m}$. 


\subsection{Candidacidal Efficacy of PAFC}

The time course of cell death caused by PAFC was detected using the cell death specific dye PI with FACS analysis (Table 3). Exposure of C. albicans ${ }^{\text {fluS }}$ to $1 \times \mathrm{IC}_{90}(2.5 \mu \mathrm{M})$ PAFC resulted in a time dependent increase in the proportion of PI positive cells after $1 \mathrm{~h}$ and $8 \mathrm{~h}$ of incubation. Interestingly, after a $24 \mathrm{~h}$ incubation the number of cells with a PI-positive phenotype dropped below $1 \%$, suggesting that surviving cells had resumed growth. The treatment of $C$. albicans $s^{f l u R}$ with PAFC similarly induced an increase in PI-positive cells between $1 \mathrm{~h}$ and $8 \mathrm{~h}$ of exposure, though in a slightly delayed manner. In strong contrast to the C. albicans ${ }^{f l u S}$, however, the percentage of C. albicans ${ }^{f l u R}$ cells with a PI-positive phenotype further increased with time and reached more than $70 \%$ after $24 \mathrm{~h}$, indicating that a high proportion of cells suffered from plasma membrane permeabilization due to PAFC treatment.

Table 3. PI-positive C. albicans cells at $1 \mathrm{~h}, 8 \mathrm{~h}$ and $24 \mathrm{~h}$ of PAFC treatment evaluated by FACS analysis $\S$.

\begin{tabular}{cccccc}
\hline Strain & Untreated & $\mathbf{1 ~ h}$ & $\mathbf{8} \mathbf{h}$ & $\mathbf{2 4} \mathbf{~ h}$ & EtOH \\
\hline C. albicans $f l u S$ & $0.10 \pm 0.1$ & $38.10 \pm 0.8^{* *}$ & $60.95 \pm 12.0^{* *}$ & $0.89 \pm 0.3$ & $99.17 \pm 3.1^{* *}$ \\
C. albicans $^{f l u R}$ & $0.09 \pm 0.04$ & $17.37 \pm 2.3^{* *}$ & $53.30 \pm 5.6^{* *}$ & $77.95 \pm 11.7^{* *}$ & $99.17 \pm 5.4^{* *}$ \\
\hline
\end{tabular}

$\S$ Values of cells with PI-positive phenotype are given in $\%$ of all cells counted $(100 \%)$. ${ }^{* *} p \leq 0.005$.

These data were confirmed by using CFU determinations after the exposure of $C$. albicans cells to increasing PAFC concentrations $(2.5-10 \mu \mathrm{M})$ corresponding to $1 \times \mathrm{IC}_{90}, 2 \times \mathrm{IC}_{90}$ and $4 \times \mathrm{IC}_{90}$ in a time course $\left(1 \mathrm{~h}, 8 \mathrm{~h}, 24 \mathrm{~h}\right.$ ) (Figure 6). In C. albicans ${ }^{f l u S}$, only $21 \% \pm 2.0 \%$ survived the 8 -h treatment with $1 \times \mathrm{IC}_{90}$, but after $24 \mathrm{~h}$ of exposure the $\mathrm{CFU}$ increased again to $49.5 \% \pm 2.5 \%$, indicating that surviving cells had resumed growth (Figure $6 \mathrm{~A}$ ). In contrast, $1 \times \mathrm{IC}_{90}$ PAFC treatment of C. albicans ${ }^{\text {fluR }}$ gave higher CFU numbers $(31.0 \% \pm 0.7 \%)$ after $8 \mathrm{~h}$, but very few cells survived the 24 -h treatment $(1.1 \% \pm 0.001 \%)$ (Figure 6B). This time-dependent trend was strain specific and apparent at all concentrations tested. These results comfirm the data generated by FACS and suggest that while PAFC killed C. albicans ${ }^{f l u S}$ cells quickly, the survivors of the treatment proliferated again. In contrast, PAFC had a delayed action on C. albicans ${ }^{f l u R}$ but was ultimately more effective as a fungicide.

\subsection{Intracellular ROS Induction by PAFC}

Studies on the mode of action of fungal AMPs have shown that their activity is often closely linked with the induction of iROS $[13,35,36]$. The formation of iROS in Candida cells in response to PAFC was therefore investigated by fluorescence microscopy (Supplementary Materials, experimental procedures). C. albicans cells exposed to $1 \times \mathrm{IC}_{90}$ PAFC $(2.5 \mu \mathrm{M})$ for $8 \mathrm{~h}$ were loaded with the non-fluorescent dye dichlorodihydrofluorescein diacetate $\left(\mathrm{H}_{2} \mathrm{DCFDA}\right)$. In the presence of $\mathrm{iROS}$, this compound is converted intracellularly to the fluorescent dichlorofluorescein (DCF). As depicted in Figure 7, both C. albicans strains suffered from iROS induction by PAFC, just like the positive control cells, which had been exposed to $10 \mu \mathrm{g} \mathrm{mL}^{-1}$ of the ROS inducing polyene drug nystatin. Untreated control cells did not show any DCF specific signal (Figure 7). 

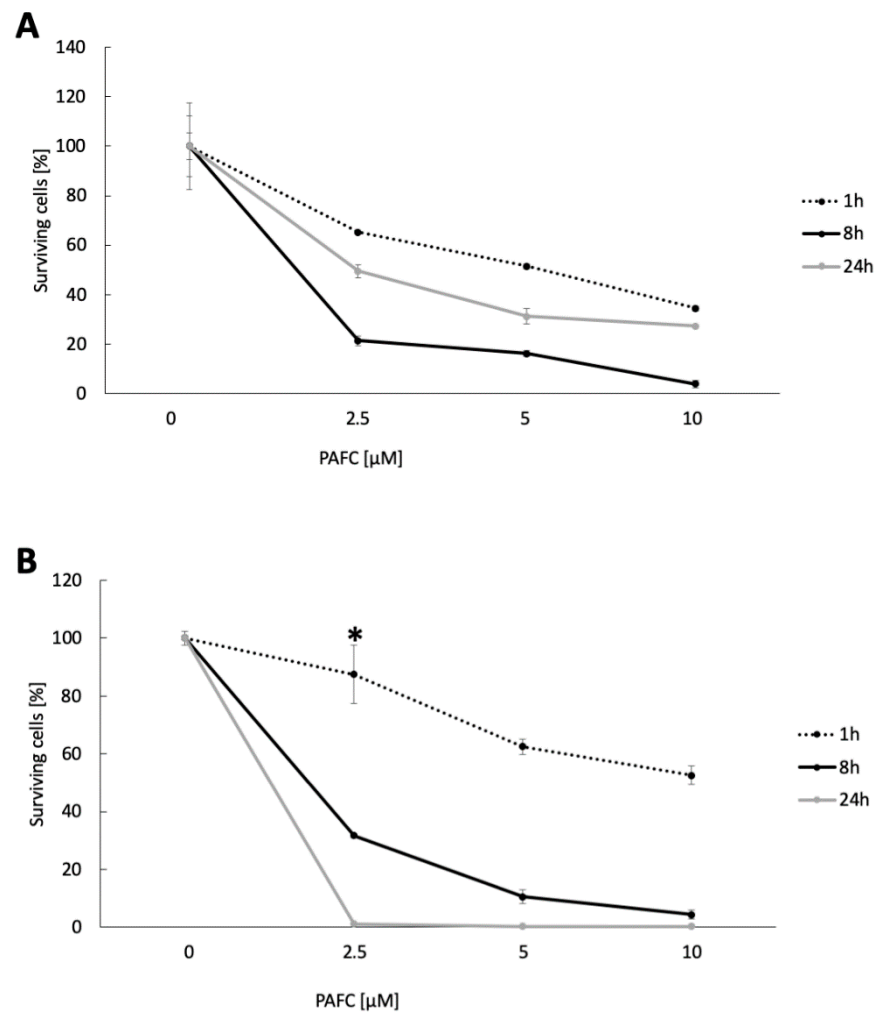

Figure 6. Candidacidal activity of PAFC. CFU of (A) C. albicans ${ }^{f l u S}$ and (B) C. albicans ${ }^{f l u R}$ cells after PAFC treatment $(2.5-10 \mu \mathrm{M})$ for $1 \mathrm{~h}, 8 \mathrm{~h}$ and $24 \mathrm{~h}$. Untreated cells served as growth control and the CFU counts were set to be $100 \%$ surviving cells. The mean \pm SD (technical quadruplicates of one representative experiment out of two biological replicates) is shown. A two-sample Student's $t$-test was applied to calculate the significant difference between the treated samples compared to the untreated growth control ( $p \leq 0.005$ for all values shown, except for $\left.{ }^{*} p<0.1\right)$.

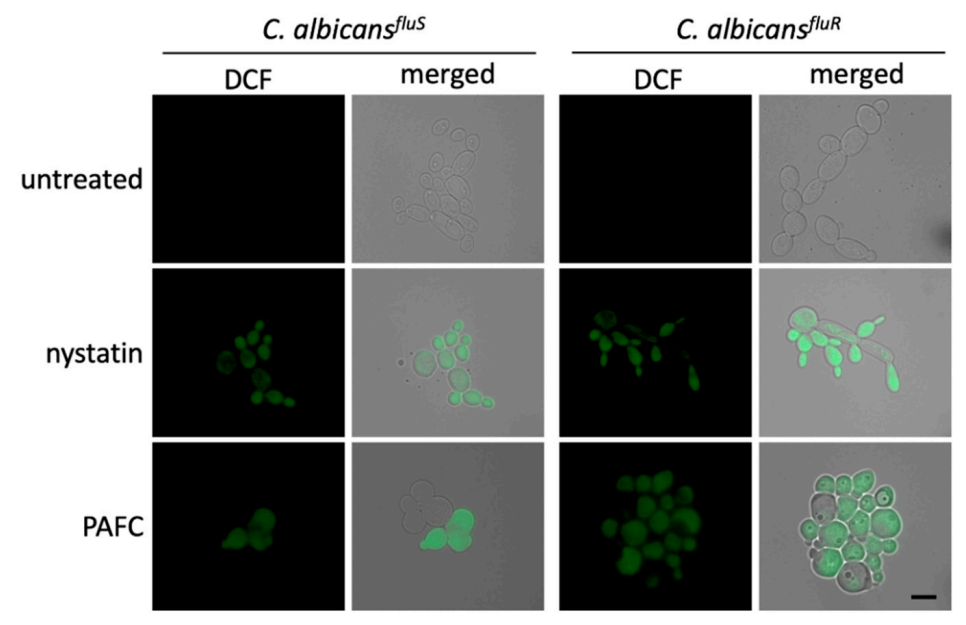

Figure 7. Induction of iROS by PAFC. Fluorescence microscopy of DCF-positive C. albicans ${ }^{f l u S}$ and C. albicans ${ }^{\text {fluR }}$ cells to visualize iROS burden after exposure to $1 \times \mathrm{IC}_{90}(2.5 \mu \mathrm{M})$ PAFC for $8 \mathrm{~h}$ at $30{ }^{\circ} \mathrm{C}$ and continuous shaking at $160 \mathrm{rpm}$. The samples were washed in PBS before incubation for $30 \mathrm{~min}$ with $\mathrm{H}_{2}$ DCFDA ( $5 \mathrm{ng} \mu \mathrm{L}^{-1}$ ). Excess of fluorescent dye was removed by washing in PBS and the cells were mounted on glass slides for evaluation of iROS induction by fluorescence microscopy. Cells without treatment and exposed to nystatin $\left(10 \mu \mathrm{g} \mathrm{mL}^{-1}\right)$ were used as negative and iROS-positive controls, respectively. The merged images show the DCF signal (green) superimposed with the Candida cells visualized with brightfield microscopy. One representative experiment out of three independent experiments is shown. Scale bar, $5 \mu \mathrm{m}$. 


\subsection{Testing of Serum-, Ion-, Thermotolerance and Hemolytic Activity of PAFC}

The tolerance of PAFC to serum compounds, high ion concentrations and extreme temperature as well as the lack of adverse effects in the host are important prerequisites for considering this AMP for a potential medical application in the future. The presence of 5-15\% inactivated fetal calf serum in the medium reduced PAFC activity against C. albicans ${ }^{f l u S}$ in a dose-dependent manner (Figure 8). Similarly, the supplementation of the growth medium with $1.25-10 \mathrm{mM} \mathrm{MgCl}, \mathrm{NaCl}_{2}$ and $\mathrm{CaCl}_{2}$ counteracted the PAFC activity in a concentration dependent manner, with PAFC being most sensitive to $\mathrm{MgCl}_{2}$ (Figure S9). The heating of PAFC to $95^{\circ} \mathrm{C}$ for $5 \mathrm{~min}$ and cooling to $25^{\circ} \mathrm{C}$ had no adverse effect on its antifungal efficacy with retention of an $\mathrm{IC}_{90}$ of $2.5 \mu \mathrm{M}$ by C. albicans ${ }^{f l u S}$. PAFC reduced the fungal growth after $24 \mathrm{~h}$ of incubation to $7.5 \pm 2.7 \%$ and to $5.8 \pm 4.2 \%$ before and after its thermal treatment, respectively, which underlined its high thermotolerance. Finally, PAFC showed no hemolytic activity when tested on sheep erythrocytes in an agar diffusion assay using Columbia blood agar plates (Figure S10).

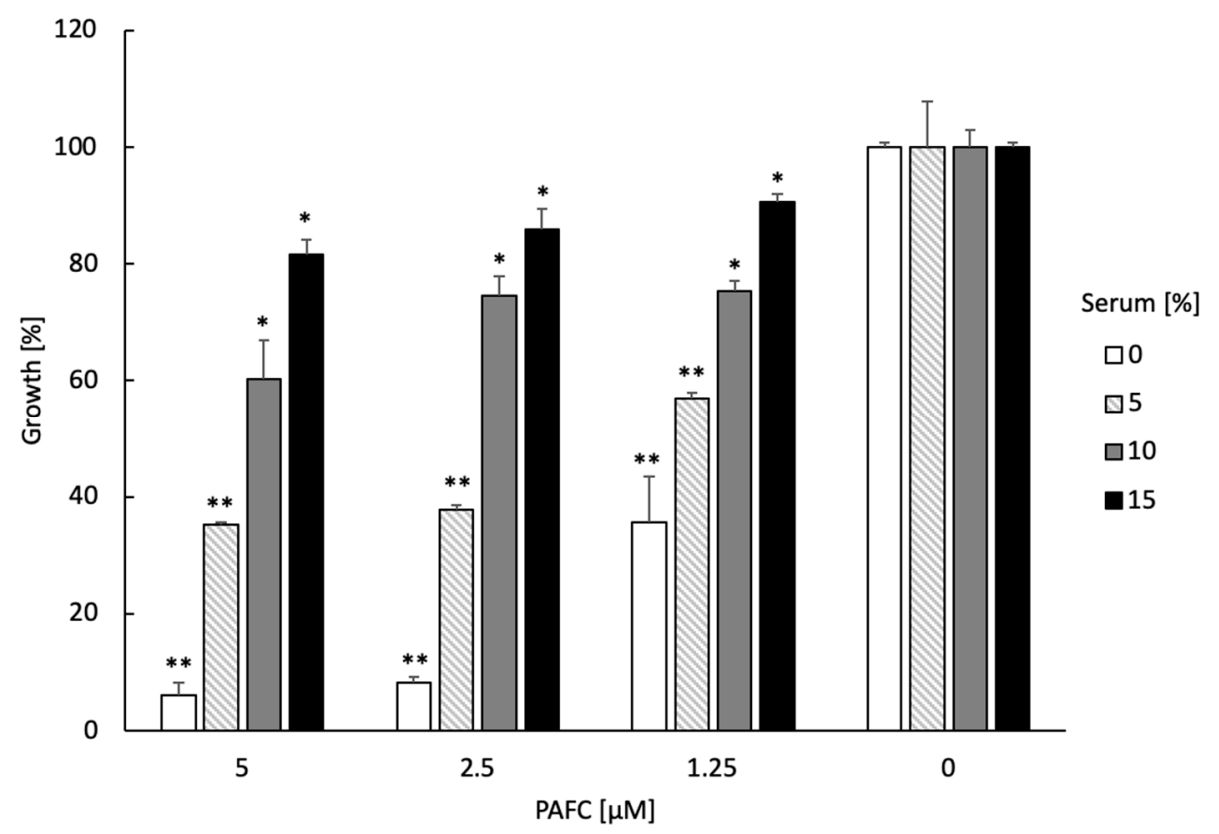

Figure 8. Serum sensitivity of PAFC. The activity of $0.5 \times \mathrm{IC}_{90}(1.25 \mu \mathrm{M}), 1 \times \mathrm{IC}_{90}(2.5 \mu \mathrm{M})$ and $2 \times \mathrm{IC}_{90}(5.0 \mu \mathrm{M})$ PAFC was tested on C. albicans ${ }^{f l u S}$ in the presence of increasing concentrations $(0-15 \%)$ of inactivated fetal calf serum in a microdilution broth assay. Candida cells without PAFC treatment $(0 \mu \mathrm{M})$ were used as control representing 100\% growth in the presence of $0-15 \%$ serum. The mean \pm SD (technical triplicate of one representative experiment out of two biological replicates) is shown. A two-sample Student's t-test was applied to calculate the significant difference between the serum-treated samples compared to the untreated growth control ${ }^{*} p \leq 0.05$ and $\left.{ }^{* *} p \leq 0.005\right)$.

\section{Discussion}

We have predicted the structure, studied the expression and characterized the antifungal mode of action of PAFC, which phylogenetically belongs to the BP group and represents-apart from PAF and PAFB $[8,9,13,37]$ - the third and previously uncharacterized AMP from the industrial strain P. chrysogenum Q176.

Similar to the crystal structure of the P. brevicompactum BP, in silico analysis of PAFC suggested a $\beta$-fold structure containing five antiparallel $\beta$-strands. Notably, for PeAfpC, a $\beta$-sheet structure composed of only three $\beta$-strands was predicted [12]. This discrepancy could result from the different in silico approach and prediction software applied to model the proteins. The disulfide bonds in cysteine-rich AMPs mediate high tolerance to harsh environmental conditions [38]. For Pc-Arctin, 
a high thermal stability but low ion tolerance and low proteolytic stability has been reported [10]. In line with this observation, PAFC showed a high sensitivity to serum and ions but thermal tolerance under the experimental conditions applied. The positively charged funnel-like opening predicted for PAFC could be involved in protein function, such as ligand binding and/or interaction with negatively charged membrane compounds of the fungal target cells, as suggested for this motif in BP $[30,39,40]$. A detailed analysis by nuclear magnetic resonance to resolve the PAFC solution structure is in progress.

The presence of the pafC transcripts in the mycelium of shaking submersed and surface cultures grown on solid medium, but not in dormant conidia or germinated conidia, indicated that PAFC might play a role after colony establishment in fungal growth and/or differentiation of P. chrysogenum. This assumption was supported by the finding that $p a f C$ transcription started in the mycelia of surface cultures at the onset of sporulation.

It is generally hypothesized that AMPs from filamentous fungi-apart from their antifungal activity-fullfill additional functions in the host during adaptation to environmental conditions [41,42]. In P. chrysogenum roles of PAF and PAFB were reported in sensing/signaling during growth, differentiation and/or asexual sporulation $[8,24,41]$ but detailed knowledge at the molecular level of the role of fungal AMPs in adaptive responses is still lacking. However, we have shown for the first time that the three P. chrysogenum AMPs PAF, PAFB and PAFC are abundantly secreted together into the exudate of old sporulating surface colonies grown on rich medium. Generally, fungal exudates contain secondary metabolites, enzymes and other by-products that are assumed to support cell survival under unfavorable environmental conditions. These liquid reservoirs can be reabsorbed when needed [43]. Indeed, these droplets and the exudate below the colony disappeared with longer incubation. This observation could indicate that exudate production in P. chrysogenum is related to nutrient access and the age of the mycelium.

The amount of endogenous PAFC was insufficient to provide the purified protein needed for characterization of its antifungal activity. Instead, we used a well-established P. chrysogenum-based expression system to produce recombinant PAFC. We obtained protein yields better than those achieved previously with other recombinant AMPs using this system $[9,12,13,26,27,44-48]$.

The BP cluster AMPs were poorly characterized with regard to their potential medical applicability. Our study shows the in vitro growth inhibitory efficacy of a BP cluster protein against opportunistic pathogenic fungi of the genus Candida. The anti-Candida effective concentration range of PAFC resembled that of PAF and PAFB, the latter showing the highest efficacy against the NAC species C. glabrata, $C$. krusei and C. parapsilosis $\left(\mathrm{IC}_{90} 0.6 \mu \mathrm{M}\right.$ ) with $\mathrm{PAF}$ being most effective against $C$. parapsilosis $\left(\mathrm{IC}_{90} 2.5 \mu \mathrm{M}\right)[7,9]$. The growth inhibitory activity of Pc-Arctin from P. chrysogenum A096 was tested on the common environmental mold Paecilomyces variotii, the plant pathogen Alternaria longipes, and the biofungicide Trichoderma viride [10]. For the P. brevicompactum BP, growth inhibitory activity against Saccharomyces cerevisiae was reported [11], whereas no antifungal activity was detected for PeAfpC [12].

To dissect in more detail the antifungal mode of action of PAFC, we used two strains of the most prevalent human pathogenic yeast, the fluconazole-sensitive $C$. albicans ${ }^{\text {flu } S}$ and the fluconazole-resistant clinical isolate C. albican fluR [16], whereby the latter strain still proliferated in the presence of the highest fluconazole concentration applied in this study. The molecular basis for the fluconazole resistance of C. albicans ${ }^{f l u R}$ is not known and subject of current investigations.

Both $C$. albicans strains exhibited the same $\mathrm{IC}_{90}$ value $(2.5 \mu \mathrm{M})$. However, the broth microdilution assays show effects on growth but not on the killing potential of an antifungal compound. Therefore, we applied plating assays for CFU determination plus SEM, CLSM and FACS to visualize and quantitate the fungicidal efficacy of PAFC. Our data indicated that PAFC acted in a fungicidal way on sessile and planktonic cells of both C. albicans strains under the test conditions applied, though the efficacy was higher against $C$. albicans ${ }^{f l u R}$ than against $C$. albicans ${ }^{f l u S}$. After $24 \mathrm{~h}$ of incubation PAFC killed more planktonic and sessile cells of C. albicans ${ }^{f l u R}$ than of C. albicans ${ }^{f l u S}$. Interestingly, cells of the latter strain resumed growth after $24 \mathrm{~h}$ of PAFC exposure, which suggests an adaptive response to PAFC treatment. In contrast, $C$. albicans ${ }^{f l u R}$ might lack the ability to respond adequately to the 
antifungal PAFC action [49]. It is known that drug resistance can be acquired at the cost of cellular fitness, leading to a disadvantage for the organism under unfavorable conditions in the absence of the specific drug [50]. Further investigations are needed to clarify, if azole-resistant $C$. albicans strains are generally more susceptible to AMPs than sensitive ones. In this respect, the comparison of several well characterized drug-resistant clinical isolates with standard strains for PAFC susceptibility or the screening of drug-sensitive parental and resistant daughter strains isolated from the same patient could be supportive.

The cell damage induced by PAFC resembled that reported for the candidacidal-acting Neosartorya fischeri antifungal protein 2 (NFAP2) [16]. However, our qualitative analysis by CLSM revealed that cell death in C. albicans requires PAFC uptake and cytoplasmic localization before plasma membrane permeabilization occurs pointing towards an intracellular target. This mode of action strongly resembles that of $P$. chrysogenum PAF and PAFB $[9,25,27]$, the N. fischeri antifungal protein NFAP $[48]$ and synthetic antifungal peptides, e.g., PAF26 [51]. Notably, PAFC activity was closely linked to the accumulation of iROS, which is generally recognized as a trigger for apoptotic cell death in C. albicans [52]. Indeed, oxidative stress seems to be a common phenotypic marker of AMP-mediated antifungal activity as reported for PAF $[13,53]$, several plant defensins $[54,55]$ and synthetic antifungal peptides $[13,56]$.

\section{Conclusions}

The emerging drug resistance of human pathogenic fungi and the limited number of antifungal drugs requires the urgent identification of new antifungal compounds with novel mechanism of action [2]. We have shown that PAFC is a promising new antifungal biomolecule. It can be produced in high yields and quality in P. chrysogenum, a generally recognized as safe organism [57]. The recombinant PAFC effectively inhibited the growth of the opportunistic human pathogen C. albicans and exhibited candidacidal activity with high efficacy against a fluconazole-resistant C. albicans clinical isolate. The high thermotolerance and the lack of hemolytic activity further supports its potential applicability in clinical therapy. Similar, to many other cysteine-rich, cationic AMPs from filamentous fungi $[8,10,27,53,58]$ PAFC also exhibited serum and cation sensitivity, which may hamper an intravenous application to combat severe systemic fungal infections. Instead, PAFC might help to develop new drugs for topical prevention or cure of fungal nail, skin and mucosal infections while repeated application of PAFC may be required to maintain its candidacidal efficacy. Furthermore, rational design could be a promising option to improve the antifungal efficacy of PAFC and overcome features that limit its potential for medical application.

Supplementary Materials: The following are available online at http://www.mdpi.com/2309-608X/6/3/141/s1, Table S1. Fungal and bacterial strains used in this study; Table S2. Composition of media and solutions used in this study; Table S3. PCR conditions applied in this study; Table S4. Oligonucleotides used in this study; Figure S1. Exudate formation of P. chrysogenum surface colonies on $2 \times P c M M$ agar; Figure S2. Cloning of the expression vector pSK275_pafC; Figure S3. Amino acid alignment of PAFC and orthologous AMPs; Figure S4. Ramachandran plot of the PAFC model; Figure S5. Expression of pafC, paf and pafB in synchronized surface cultures of P. chrysogenum over a time course of $12-48 \mathrm{~h}$ of incubation; Figure S6. Western blot analysis to prove the binding of the PeAfpC antibody to PAFC; Figure S7. Purification of recombinant PAFC; Figure S8. Fluorescence microscopy for the localization of nuclei and PAFC-Bd; Figure S9. Ion tolerance of PAFC; Figure S10. Hemolytic activity of PAFC tested with agar diffusion assay; Video S1. Rotation of the PAFC model colored according to the Coulomb scale (blue: electropositive, red: electronegative); Video S2. Rotation of the PAFC model colored according to the Kyte-Doolittle scale (blue: hydrophilic, orange: hydrophobic).

Author Contributions: Conceptualization, F.M., L.G. and G.K.T.; formal analysis, J.H., and L.G.; investigation, J.H., A.K., C.P., A.F. and G.V.; data validation, J.H., A.K., C.P., A.F., G.V., L.G. and F.M.; visualization, J.H., A.K., C.P. and A.F.; supervision, L.G. and F.M.; resources, J.F.M. and P.M.; writing-original draft preparation, J.H., A.K., C.P., A.F., G.V., J.F.M., P.M., G.K.T., L.G. and F.M.; writing-review and editing, J.H., A.K., C.P., A.F., G.V., J.F.M., P.M., G.K.T., L.G. and F.M.; project administration, L.G. and F.M.; funding acquisition, F.M, G.K.T. and L.G. All authors have read and agreed to the published version of the manuscript.

Funding: This study was supported by the Austrian Science Fund FWF (I3132-B21) to FM and Open Access Funding by the FWF covers the publication costs. JH was financed by the Scholarship of the Aktion Österreich-Ungarn. LG is financed by the Postdoctoral Excellence Programme (PD 135248) and the bilateral Austrian-Hungarian Joint Research Project (ANN 131341) of the Hungarian National Research, Development and Innovation (NKFIH) 
Office. Research of LG was supported by the János Bolyai Research Scholarship of the Hungarian Academy of Sciences. The present work of LG was supported by the ÚNKP-20-5 New National Excellence Program of the Ministry for Innovation and Technology (ITM). GV and GKT were supported by the NKFIH Office (GINOP-2.3.2-15-2016-00014, 20391-3/2018/FEKUSTRAT) and the ITM (TUDFO/47138-1/2019-ITM FIKP). JFM and PM were supported by grant RTI2018-101115B-C21 from the "Ministerio de Ciencia, Innovación, y Universidades" (Spain) (MICINN/FEDER Funds).

Acknowledgments: We thank Doris Bratschun-Khan, Anna Huber and Anant Kakar for technical support. The Candida albicans 27700 strain was a kind gift from Renátó Kovács (Department of Medical Microbiology, Faculty of Medicine, University of Debrecen, Debrecen, Hungary).

Conflicts of Interest: The funders had no role in the design of the study; in the collection, analyses, or interpretation of data; in the writing of the manuscript, or in the decision to publish the results.

\section{References}

1. Vallabhaneni, S.; Mody, R.K.; Walker, T.; Chiller, T. The global burden of fungal diseases. Infect. Dis. Clin. N. Am. 2016, 30, 1-11. [CrossRef]

2. Perlin, D.S.; Rautemaa-Richardson, R.; Alastruey-Izquierdo, A. The global problem of antifungal resistance: Prevalence, mechanisms, and management. Lancet Infect. Dis. 2017, 17, e383-e392. [CrossRef]

3. Berkow, E.L. Fluconazole resistance in Candida species: A current perspective. Infect. Drug Resist. 2017, 10, 237-245. [CrossRef] [PubMed]

4. Nobile, C.J.; Johnson, A.D. Candida albicans biofilms and human disease. Annu. Rev. Microbiol. 2005, 69, 71-92. [CrossRef] [PubMed]

5. McManus, D. Side effects of drugs annual: A worldwide yearly survey of new data in adverse drug reactions. In Antifungal Drugs; Sidhartha, D.R., Ed.; Elsevier: Amsterdam, The Netherlands, 2017; Volume 38, pp. 243-253.

6. Pristov, K.E.; Ghannoum, M.A. Resistance of Candida to azoles and echinocandins worldwide. Clin. Microbiol. Infect. 2019, 25, 792-798. [CrossRef]

7. Galgóczy, L.; Yap, A.; Marx, F. Cysteine-rich antifungal proteins from filamentous fungi are promising bioactive natural compounds in anti-Candida therapy. Isr. J. Chem. 2019, 59, 360-370. [CrossRef]

8. Huber, A.; Galgóczy, L.; Váradi, G.; Holzknecht, J.; Kakar, A.; Malanovic, N.; Leber, R.; Koch, J.; Keller, M.A.; Batta, G.; et al. Two small, cysteine-rich and cationic antifungal proteins from Penicillium chrysogenum: A comparative study of PAF and PAFB. Biochim. Biophys. Acta Biomembr. 2020, 1862, 183246. [CrossRef]

9. Huber, A.; Hajdu, D.; Bratschun-Khan, D.; Gáspári, Z.; Varbanov, M.; Philippot, S.; Fizil, A.; Czajlik, A.; Kele, Z.; Sonderegger, C.; et al. New antimicrobial potential and structural properties of PAFB: A cationic, cysteine-rich protein from Penicillium chrysogenum Q176. Sci. Rep. 2018, 8, 1751. [CrossRef]

10. Chen, Z.; Ao, J.; Yang, W.; Jiao, L.; Zheng, T.; Chen, X. Purification and characterization of a novel antifungal protein secreted by Penicillium chrysogenum from an arctic sediment. Appl. Microbiol. Biotechnol. 2013, 97, 10381-10390. [CrossRef]

11. Seibold, M.; Wolschann, P.; Bodevin, S.; Olsen, O. Properties of the bubble protein, a defensin and an abundant component of a fungal exudate. Peptides 2011, 32, 1989-1995. [CrossRef]

12. Garrigues, S.; Gandía, M.; Castillo, L.; Coca, M.; Marx, F.; Manzanares, P.; Marcos, J.F.; Manzanares, P. Three antifungal proteins from Penicillium expansum: Different patterns of production and antifungal activity. Front Microbiol. 2018, 9, 2370. [CrossRef] [PubMed]

13. Sonderegger, C.; Váradi, G.; Galgóczy, L.; Kocsubé, S.; Posch, W.; Borics, A.; Dubrac, S.; Tóth, G.K.; Wilfingseder, D.; Marx, F. The evolutionary conserved $\gamma$-core motif influences the anti-Candida activity of the Penicillium chrysogenum antifungal protein PAF. Front Microbiol. 2018, 9, 1655. [CrossRef] [PubMed]

14. Hoff, B.; Pöggeler, S.; Kück, U. Eighty years after its discovery, Fleming's Penicillium strain discloses the secret of its sex. Eukaryot. Cell 2008, 7, 465-470. [CrossRef] [PubMed]

15. Martín, J.F. Insight into the genome of diverse Pencillium chrysogenum strains: Specific genes, cluster duplications and DNA fragment translocations. Int. J. Mol. Sci. 2020, 21, 3936. [CrossRef] [PubMed]

16. Kovács, R.; Holzknecht, J.; Hargitai, Z.; Papp, C.; Farkas, A.; Borics, A.; Tóth, L.; Váradi, G.; Tóth, G.; Kovács, I.; et al. In vivo applicability of Neosartorya fischeri antifungal protein 2 (NFAP2) in treatment of vulvovaginal candidiasis. Antimicrob. Agents Chemother. 2019. [CrossRef] [PubMed] 
17. Yang, J.; Yan, R.; Roy, A.; Xu, D.; Poisson, J.; Zhang, Y. The I-TASSER suite: Protein structure and function prediction. Nat. Methods 2015, 12, 7-8. [CrossRef] [PubMed]

18. Lovell, S.C.; Davis, I.W.; Arendall, W.B., 3rd; de Bakker, P.I.; Word, J.M.; Prisant, M.G.; Richardson, J.S.; Richardson, D.C. Structure validation by Calpha geometry: Phi, psi and Cbeta deviation. Proteins 2003, 50, 437-450. [CrossRef] [PubMed]

19. Ceroni, A.; Passerini, A.; Vullo, A.; Frasconi, P. DISULFIND: A disulfide bonding state and cysteine connectivity prediction server. Nucleic. Acids Res. 2006, 34, W177-W181. [CrossRef]

20. Leitner, A.; Walzthoeni, T.; Kahraman, A.; Herzog, F.; Rinner, O.; Beck, M.; Aebersold, R. Probing native protein structures by chemical cross-linking, mass spectrometry, and bioinformatics. Mol. Cell. Proteom. 2010, 9, 1634-1649. [CrossRef]

21. Pettersen, E.F.; Goddard, T.D.; Huang, C.C.; Couch, G.S.; Greenblatt, D.M.; Meng, E.C.; Ferrin, T.E. UCSF Chimera-A visualization system for exploratory research and analysis. J. Comput. Chem. 2004, 13, 1605-1612. [CrossRef]

22. Waterhouse, A.M.; Procter, J.B.; Martin, D.M.; Clamp, M.; Barton, G.J. Jalview Version 2-a multiple sequence alignment editor and analysis workbench. Bioinformatics 2009, 5, 1189-1191. [CrossRef]

23. Sievers, F.; Wilm, A.; Dineen, D.; Gibson, T.J.; Karplus, K.; Li, W.; Lopez, R.; McWilliam, H.; Remmert, M.; Söding, J.; et al. Fast, scalable generation of high-quality protein multiple sequence alignments using Clustal Omega. Mol. Syst. Biol. 2011, 7, 539. [CrossRef]

24. Hegedüs, N.; Sigl, C.; Zadra, I.; Pócsi, I.; Marx, F. The paf gene product modulates asexual development in Penicillium chrysogenum. J. Basic Microbiol. 2011, 51, 253-262. [CrossRef]

25. Oberparleiter, C.; Kaiserer, L.; Haas, H.; Ladurner, P.; Andratsch, M.; Marx, F. Active internalization of the Penicillium chrysogenum antifungal protein PAF in sensitive Aspergilli. Antimicrob. Agents Chemother. 2003, 47, 3598-3601. [CrossRef]

26. Sonderegger, C.; Galgóczy, L.; Garrigues, S.; Fizil, Á.; Borics, A.; Manzanares, P.; Hegedüs, N.; Huber, A.; Marcos, J.F.; Batta, G.; et al. A Penicillium chrysogenum-based expression system for the production of small, cysteine-rich antifungal proteins for structural and functional analyses. Microb. Cell Fact. 2016, 15, 192. [CrossRef]

27. Sonderegger, C.; Fizil, Á.; Burtscher, L.; Hajdu, D.; Muñoz, A.; Gáspári, Z.; Read., N.D.; Batta, G.; Marx, F. D19S mutation of the cationic, cysteine-rich protein PAF: Novel insights into its structural dynamics, thermal unfolding and antifungal function. PLoS ONE 2017, 12, e0169920. [CrossRef]

28. Schindelin, J.; Arganda-Carreras, I.; Frise, E.; Kaynig, V.; Longair, M.; Pietzsch, T.; Preibisch, S.; Rueden, C.; Saalfeld, S.; Schmid, B.; et al. Fiji: An open-source platform for biological-image analysis. Nat. Methods 2012, 9, 676-682. [CrossRef]

29. Yount, N.Y.; Yeaman, M.R. Multidimensional signatures in antimicrobial peptides. Proc. Natl. Acad. Sci. USA 2004, 101, 7363-7368. [CrossRef]

30. Olsen, J.G.; Flensburg, C.; Olsen, O.; Bricogne, G.; Henriksen, A. Solving the structure of the bubble protein using the anomalous sulfur signal from single-crystal in-house $\mathrm{Cu}$ Kalpha diffraction data only. Acta Cryst. D Biol Cryst. 2004, 60, 250-255. [CrossRef]

31. Kyte, J.; Doolittle, R.F. A simple method for displaying the hydropathic character of a protein. J. Mol. Biol. 1982, 157, 105-132. [CrossRef]

32. Cantoral, J.M.; Díez, B.; Barredo, J.; Alvarez, E.; Martín, J.F. High-frequency transformation of Penicillium chrysogenum. Nat. Biotechnol. 1987, 5, 494-497. [CrossRef]

33. Kolar, M.; Punt, P.J.; van den Hondel, C.A.; Schwab, H. Transformation of Penicillium chrysogenum using dominant selection markers and expression of an Escherichia coli lacZ fusion gene. Gene 1988, 62, 127-134. [CrossRef]

34. Polke, M.; Hube, B.; Jacobsen, I.D. Candida survival strategies. Adv. Appl. Microbiol. 2015, 91, $139-235$. [CrossRef] [PubMed]

35. Aerts, A.M.; François, I.E.; Meert, E.M.; Li, Q.T.; Cammue, B.P.; Thevissen, K. The antifungal activity of RsAFP2, a plant defensin from Raphanus sativus, involves the induction of reactive oxygen species in Candida albicans. J. Mol. Microbiol. Biotechnol. 2007, 13, 243-247. [CrossRef]

36. Muñoz, A.; Marcos, J.F.; Read, N.D. Concentration-dependent mechanisms of cell penetration and killing by the de novo designed antifungal hexapeptide PAF26. Mol. Microbiol. 2012, 85, 89-106. [CrossRef] 
37. Marx, F.; Binder, U.; Leiter, É.; Pócsi, I. The Penicillium chrysogenum antifungal protein PAF, a promising tool for the development of new antifungal therapies and fungal cell biology studies. Cell. Mol. Life Sci. 2008, 65, 445-454. [CrossRef]

38. Batta, G.; Barna, T.; Gáspári, Z.; Sándor, S.; Kövér, K.E.; Binder, U.; Sarg, B.; Kaiserer, L.; Chillar, A.K.; Eigentler, A.; et al. Functional aspects of the solution structure and dynamics of PAF-A highly-stable antifungal protein from Penicillium chrysogenum. FEBS J. 2009, 276, 2875-4658. [CrossRef]

39. Laskowskie, R.A.; Rullmann, J.A.C.; MacArthur, M.W.; Kaptein, R.; Thornton, J.M. AQUA and PROCHECK-NMR: Programs for checking the quality of protein structures solved by NMR. J. Biomol. NMR 1996, 8, 477-486. [CrossRef]

40. Breustedt, D.A.; Korndo, I.P.; Redl, B.; Skerra, A. The 1.8- $\AA$ crystal structure of human tear lipocalin reveals an extended branched cavity with capacity for multiple ligands. J. Biol. Chem. 2005, 280, 484-493. [CrossRef]

41. Hegedüs, N.; Marx, F. Antifungal proteins: More than antimicrobials? Fungal. Biol. Rev. 2013, 26, $132-145$. [CrossRef]

42. Paege, N.; Jung, S.; Schäpe, P.; Müller-Hagen, D.; Ouedraogo, J.P.; Heiderich, C.; Jedamzick, J.; Nitsche, B.M.; van den Hondel, C.A.; Ram, A.F.; et al. A transcriptome meta-analysis proposes novel biological roles for the antifungal protein AnAFP in Aspergillus niger. PLoS ONE 2016, 11, e0165755. [CrossRef] [PubMed]

43. McPhee, W.J.; Cologelo, N. Fungal exudates. I. Characteristics of hyphal exudates in Fursarium culmorum. Can. J. Bot. 1977, 55, 358-365. [CrossRef]

44. Garrigues, S.; Gandía, M.; Popa, C.; Borics, A.; Marx, F.; Coca, M.; Marcos, J.F.; Manzanares, P. Efficient production and characterization of the novel and highly active antifungal protein AfpB from Penicillium digitatum. Sci. Rep. 2017, 7, 14663. [CrossRef] [PubMed]

45. Fizil, Á.; Sonderegger, C.; Czajlik, A.; Fekete, A.; Komáromi, I.; Hajdu, D.; Marx, F.; Batta, G. Calcium binding of the antifungal protein PAF: Structure, dynamics and function aspects by NMR and MD simulations. PLOS ONE 2018, 13, e0204825. [CrossRef]

46. Heredero, M.; Garrigues, S.; Gandía, M.; Marcos, J.F.; Manzanares, P. Rational design and biotechnological production of novel AfpB-PAF26 chimeric antifungal proteins. Microorganisms 2018, 6, 106. [CrossRef]

47. Tóth, L.; Váradi, G.; Borics, A.; Batta, G.; Kele, Z.; Vendrinszky, Á.; Tóth, R.; Ficze, H.; Vágvölgyi, C.; Marx, F.; et al. Anti-candidal activity and functional mapping of recombinant and synthetic Neosartorya fischeri antifungal protein 2 ( NFAP2 ). Front Microbiol. 2018, 9, 393. [CrossRef]

48. Hajdu, D.; Huber, A.; Czajlik, A.; Tóth, L.; Kele, Z.; Kocsubé, S.; Fizil, A.; Marx, F.; Galgóczy, L.; Batta, G. Solution structure and novel insights into phylogeny and mode of action of the Neosartorya (Aspergillus) fischeri antifungal protein (NFAP). Int. J. Biol. Macromol. 2019, 129, 511-522. [CrossRef]

49. Ouedraogo, J.P.; Hagen, S.; Spielvogel, A.; Engelhardt, S.; Meyer, V. Survival strategies of yeast and filamentous fungi against the antifungal protein AFP. J. Biol. Chem. 2011, 286, 13859-13868. [CrossRef]

50. Robbins, N.; Caplan, T.; Cowen, L.E. Molecular evolution of antifungal drug resistance. Annu. Rev. Microbiol. 2017, 71, 753-775. [CrossRef]

51. Muñoz, A.; Harries, E.; Contreras-Valenzuela, A.; Carmona, L.; Read, N.D.; Marcos, J.F. Two functional motifs define the interaction, internalization and toxicity of the cell-penetrating antifungal peptide PAF26 on fungal cells. PLoS ONE 2013, 8, e54813. [CrossRef]

52. Phillips, A.J.; Sudbery, I.; Ramsdale, M. Apoptosis induced by environmental stresses and amphotericin B in Candida albicans. Proc. Natl. Acad. Sci. USA 2003, 100, 14327-14332. [CrossRef] [PubMed]

53. Kaiserer, L.; Oberparleiter, C.; Weiler-Görz, R.; Burgstaller, W.; Leiter, E.; Marx, F. Characterization of the Penicillium chrysogenum antifungal protein PAF. Arch. Microbiol. 2003, 180, 204-210. [CrossRef] [PubMed]

54. Vriens, K.; Cammue, B.P.A.; Thevissen, K. Antifungal plant defensins: Mechanisms of action and production. Molecules 2014, 19, 12280-12303. [CrossRef] [PubMed]

55. Parisi, K.; Shafee, T.M.A.; Quimbar, P.; van der Weerden, N.L.; Bleackley, M.R.; Anderson, M.A. The evolution, function and mechanisms of action for plant defensins. Semin. Cell Dev. Biol. 2019, 88, 107-118. [CrossRef] [PubMed]

56. Li, R.; Chen, C.; Zhang, B.; Jing, H.; Wang, Z.; Wu, C.; Hao, P.; Kuang, Y.; Yang, M. The chromogranin A-derived antifungal peptide CGA-N9 induces apoptosis in Candida tropicalis. Biochem. J. 2019, 476, 3069-3080. [CrossRef] 
57. Bourdichon, F.; Casaregola, S.; Farrokh, C.; Frisvad, J.C.; Gerds, M.L.; Hammes, W.P.; Harnett, J.; Huys, G.; Laulund, S.; Ouwehand, A.; et al. Food fermentations: Microoganisms with technological benefical use. Int. J. Food Microbiol. 2012, 154, 87-97. [CrossRef]

58. Galgóczy, L.; Borics, A.; Virágh, M.; Ficze, H.; Váradi, G.; Kele, Z.; Marx, F. Structural Determinants of Neosartorya fischeri antifungal protein (NFAP) for folding, stability and antifungal activity. Sci. Rep. 2017, 7, 1963. [CrossRef]

C 2020 by the authors. Licensee MDPI, Basel, Switzerland. This article is an open access article distributed under the terms and conditions of the Creative Commons Attribution (CC BY) license (http://creativecommons.org/licenses/by/4.0/). 